\title{
Drivers of the winter-spring phytoplankton bloom in a pristine NW Mediterranean site, the Bay of Calvi (Corsica): A long-term study (1979-2011)
}

\author{
Anne Goffart ${ }^{\mathrm{a}, *}$, Jean-Henri Hecq ${ }^{\mathrm{a}}$, Louis Legendre ${ }^{\mathrm{b}, \mathrm{c}}$ \\ a University of Liège, Laboratory of Oceanology, MARE Centre, B6c, 15 allée du 6 août, 4000 Liège Sart-Tilman, Belgium

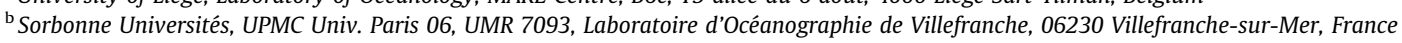 \\ ${ }^{\text {c } C N R S, ~ U M R ~ 7093, ~ L O V, ~ O b s e r v a t o i r e ~ o c e ́ a n o l o g i q u e, ~} 06230$ Villefranche-sur-Mer, France
}

\section{A R T I C L E I N F O}

\section{Article history:}

Received 1 February 2014

Received in revised form 22 May 2015

Accepted 28 May 2015

Available online 3 June 2015

\begin{abstract}
A B S T R A C T
This work is based on a long time series of data collected in the well-preserved Bay of Calvi (Corsica island, Ligurian Sea, NW Mediterranean) between 1979 and 2011, which include physical characteristics (31 years), chlorophyll a (chl $a, 15$ years), and inorganic nutrients (13 years). Because samples were collected at relatively high frequencies, which ranged from daily to biweekly during the winter-spring period, it was possible to (1) evidence the key role of two interacting physical variables, i.e. water temperature and wind intensity, on nutrient replenishment and phytoplankton dynamics during the winter-spring period, (2) determine critical values of physical factors that explained interannual variability in the replenishment of surface nutrients and the winter-spring phytoplankton bloom, and (3) identify previously unrecognised characteristics of the planktonic ecosystem. Over the $>30$ year observation period, the main driver of nutrient replenishment and phytoplankton ( $\mathrm{chl} a$ ) development was the number of wind events (mean daily wind speed $>5 \mathrm{~m} \mathrm{~s}^{-1}$ ) during the cold-water period (subsurface water $\leqslant 13.5^{\circ} \mathrm{C}$ ). According to winter intensity, there were strong differences in both the duration and intensity of nutrient fertilisation and phytoplankton blooms ( $\mathrm{chl} a$ ). The trophic character of the Bay of Calvi changed according to years, and ranged from very oligotrophic (i.e. subtropical regime, characterised by low seasonal variability) to mesotrophic (i.e. temperate regime, with a well-marked increase in nutrient concentrations and chl $a$ during the winter-spring period) during mild and moderate winters, respectively. A third regime occurred during severe winters characterised by specific wind conditions (i.e. high frequency of northeasterly winds), when Mediterranean "high nutrient - low chlorophyll" conditions occurred as a result of enhanced crossshore exchanges and associated offshore export of the nutrient-rich water. There was no long-term trend (e.g. climatic) in either nutrient replenishment or the winter-spring phytoplankton bloom between 1979 and 2011, but both nutrients and chl $a$ reflected interannual and decadal changes in winter intensity.
\end{abstract}

(c) 2015 Elsevier Ltd. All rights reserved.

\section{Introduction}

Phytoplankton blooms are events of rapid production and accumulation of biomass, i.e. transient departures from the usual quasi-equilibrium, when primary production temporarily exceeds grazing and sinking losses and transport (Paerl, 1988; Legendre, 1990; Cloern, 1996). In temperate zones, exceptionally high concentrations of phytoplankton develop during relatively short periods of the year, especially at the end of winter and during spring. Annually recurrent blooms imply that the ecosystem recreates,

\footnotetext{
* Corresponding author. Tel.: +32 43665076, +33 683713223.

E-mail addresses: A.Goffart@ulg.ac.be (A. Goffart), JH.Hecq@ulg.ac.be (J.-H. Hecq), legendre@obs-vlfr.fr (L. Legendre).
}

over the autumn and winter, the conditions necessary for a buildup of biomass, showing that the winter-spring bloom is not an isolated event, but a feature of the annual cycle (Evans and Parslow, 1985; Behrenfeld, 2010).

Favourable conditions for phytoplankton growth occur when high concentrations of deep nutrients have been injected to the photic layer by vertical water exchanges, and irradiance is high enough for photosynthesis to exceed respiration (e.g. Mann and Lazier, 1996; D'Ortenzio and Prieur, 2012). The factors that cause nutrient replenishment of the upper layer by deep vertical mixing include processes that increase surface water density by cooling or evaporation, those processes being largely driven by cold air temperature and dry wind stirring (Williams and Follows, 2003; Salat et al., 2010). Mixing is particularly strong in the surface layer, 
where there are continuous exchanges of energy with the atmosphere (D'Ortenzio and Prieur, 2012).

In the Western Mediterranean Sea, the occurrence of the winter-spring phytoplankton bloom is one of the most characteristic features of planktonic ecosystems, and a second, less intense peak in phytoplankton biomass develops in some areas in late summer or autumn (Estrada et al., 1985; Zingone et al., 1995; Licandro et al., 2006). There is high variability in the timing of the blooms over the basin (e.g. Bosc et al., 2004; D'Ortenzio and Ribera d'Alcalà, 2009; Bernardello et al., 2012). In offsfore waters, the winter-spring bloom occurs between the end of February and the beginning of May (e.g. Morel and André, 1991; Marty and Chiavérini, 2010; Siokou-Frangou et al., 2010). In coastal areas, the most common pattern is the occurrence of a phytoplankton bloom in February-March (Herrera and Margalef, 1961; Estrada et al., 1985; Charles et al., 2005), but variability amongst regions and years is higher than in offshore waters. For example, peak values in chlorophyll $a$ (chl $a$ ) have been reported to occur between January in Banuyls-sur-Mer (Gulf of Lion; Neveux et al., 1975) and Blanes Bay (NE Spain; Duarte et al., 1999) and in May in the Gulf of Naples (Thyrrhenian Sea, Ribera d'Alcalà et al., 2004).

In the offshore waters and coastal areas of the Mediterranean Sea, the characteristic winter-spring bloom has been reported to develop in the upper water column when surface heating increases water column stability and thus causes the beginning of summer stratification (e.g. Estrada, 1996; Duarte et al., 1999). In these waters during the following stratified period, chl $a$ concentration in the upper layer is very low, and a well-marked deep chl $a$ maximum develops at the depth of the nitracline (Estrada et al., 1985; Marty et al., 2002).

In offshore Mediterranean waters, the strong interplay between physical processes acting on the distribution of nutrients and phytoplankton phenology has been studied at different temporal and spatial scales using both field (e.g. Andersen and Prieur, 2000; Vidussi et al., 2000; Marty et al., 2002) and modelling (e.g. Crise et al., 1999; Lazzari et al., 2012; Lavigne et al., 2013) approaches. Overall, these studies have indicated that the wind is the most relevant factor that influences the annual buildup of phytoplankton biomass (e.g. D'Ortenzio and Ribera d'Alcalà, 2009; Siokou-Frangou et al., 2010; Olita et al., 2011). However, no Mediterranean data series has had both the time resolution and duration to identify unambiguously the processes that control the interannual variability of phytoplankton blooms and quantify these processes.

Contrary to the offshore waters, few studies only have addressed the long-term responses of phytoplankton to physical forcing in Mediterranean coastal areas. The few available nutrient and phytoplankton time series concern highly urbanised areas, where long-term variability reflects the combined effects of climate and anthropogenic forcing, e.g. land-derived nutrients delivered to coastal waters by river discharges (Bernardi Aubry et al., 2004; Mozetič et al., 2010; Arin et al., 2013), fertiliser runoff and industrial effluents (Ninčević Gladan et al., 2010), urban runoff from very densely populated regions (Ribera d'Alcalà et al., 2004; Zingone et al., 2010), and aquaculture (Sara et al., 2011). The studies based on these time series could not distinguish the responses of phytoplankton to physical forcing from those induced by multiple human disturbances. To our knowledge, the only investigations in a coastal Mediterranean area free from local anthropogenic pressure have been conducted in the Bay of Calvi (Corsica, Northwestern Mediterranean; Goffart, 1992; Goffart et al., 2002; Skliris et al., 2001a).

In the present study, we use a long-term time series of observations made in the Bay of Calvi between 1979 and 2011, to investigate the effects of key natural drivers on surface nutrient replenishment, and to provide new insights on the regulation of the winter-spring phytoplankton blooms by environmental factors.

\section{Materials and methods}

\subsection{Regional setting and study area}

The Bay of Calvi (Fig. 1) is located on the western coast of Corsica island, and it opens to the north to the Ligurian Sea, which is one of the main sub-basins of the Northwestern Mediterranean Sea. The bay is influenced by the Modified Atlantic Water of the Western Corsica Current (WCC), flowing northeastwards off the bay, in quasi-geostrophic balance, and following the isobaths (Skliris et al., 2011). The WCC is $20-30 \mathrm{~km}$ wide, relatively deep $(\approx 200 \mathrm{~m})$ and stable, even if it is sometimes disturbed by mesoscale phenomena (Bethoux and Prieur, 1983; Millot, 1991; Goffart et al., 1995). It separates the lighter waters on the continental, eastern side from the denser waters of the central Ligurian Sea (Sournia et al., 1990). North of Corsica, the WCC and the more variable Eastern Corsican Current (or Tyrrhenian Current) join together to form the Northern Current, which displays pronounced variations in its seasonal structure and is usually referred to as the Liguro-Provençal current in the Ligurian Sea (Astraldi et al., 1994; Millot, 1999). As far as the pelagic ecosystem is concerned, one of the peculiarities of the Ligurian Sea is that the shelf region is more oligotrophic than the offshore areas (e.g. Sournia et al., 1990; Goffart et al., 1995; Pinca and Dallot, 1995).

The Bay of Calvi is strongly exposed to the dominant southwesterly winds (called Libeccio), and to the less frequent northeasterly winds (called Gregale). The bay is characterised by a narrow continental shelf (mean width $\approx 3 \mathrm{~km}$ ) and the presence of a deep canyon (mean depth $\approx 600 \mathrm{~m}$ ) with steep sides (bottom slope up to $40 \%$ ) that intersects the shelf in front of the city of Calvi. The depth within the bay itself reaches $70 \mathrm{~m}$, and increases rapidly offshore. The presence of the deep canyon at the mouth of the bay enhances shelf-slope exchanges, and influences the circulation within the bay. At the local scale, the mean horizontal current is deviated upstream of the canyon to form an anticyclonic gyre in the western part of the bay and a cyclonic gyre in the eastern part. Average values of current velocity obtained from long-term measurements of the subsurface currents during low wind conditions (wind speed $<4 \mathrm{~m} \mathrm{~s}^{-1}$ ) are of the order of 7 and $510^{-2} \mathrm{~m} \mathrm{~s}^{-1}$ in the western and eastern parts of the bay, respectively (Djenidi, 1985; Djenidi et al., 1987; Skliris et al., 2001b). In some cases, transient upwelling structures and input of offshore water occur during strong wind events (Brohée et al., 1989; Goffart, 1992; Skliris et al., 2001a).

The Bay of Calvi is a well-preserved, low-runoff system, i.e. local runoff from the Figarella River in the eastern part of the bay is small and irregular, which reflects the stormy Mediterranean precipitation regime. Water quality in the bay is high (Boissery et al., 2013), which is explained by the low anthropogenic pressure, i.e. absence of agricultural or industrial activities, small permanent population (ca. 5400 residents), and tourism, which is the main economic activity, limited to July and August. According to years, surface salinity ranges from 37.6 to 38.1 during winter mixing conditions, and nitrate and silicate reach maximum concentrations of 2.0-3.0 $\mu \mathrm{M}$ (same maximum values for the two nutrients) over the whole water column (Goffart, 1992; Goffart et al., 2002). During the stratified period, nutrients are depleted from surface to depth, and the nutrient inputs from runoff or human activities are too low to relax the oligotrophic conditions of the bay. A dense and continuous Posidonia oceanica meadow extends on the sandy seabed from 5 to $40 \mathrm{~m}$ (Gobert et al., 2003), and photophilic algae colonise the rocky shore from a few centimetres below the surface to $25 \mathrm{~m}$ depth (Hoffmann et al., 1992). 

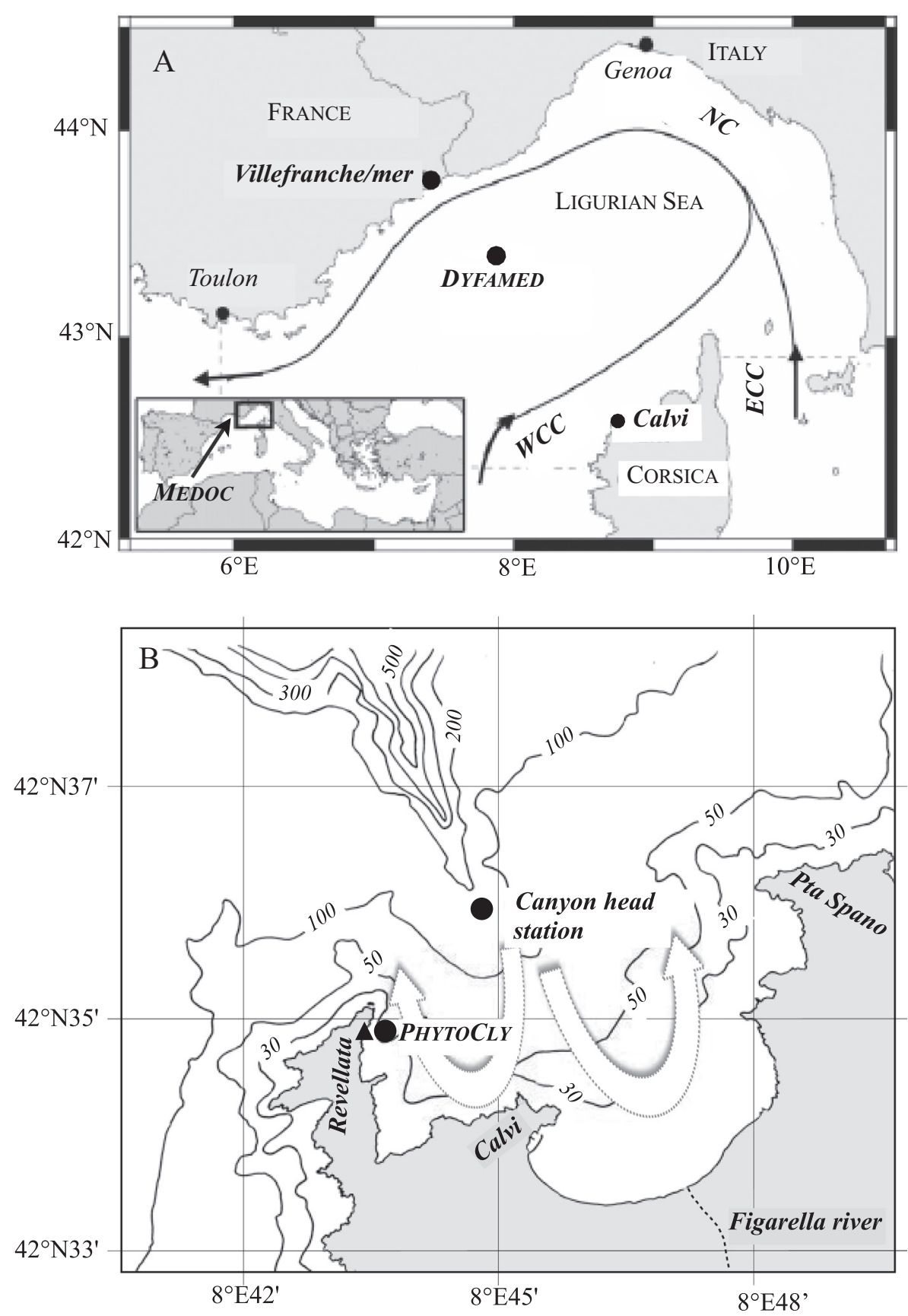

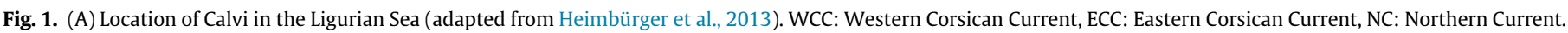

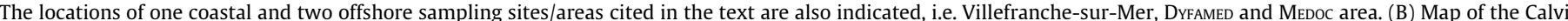

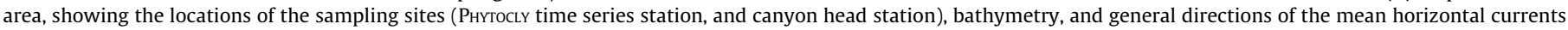

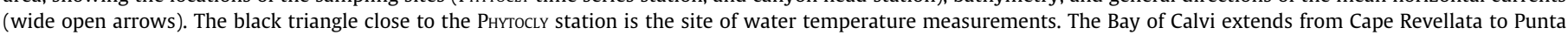
(Point) Spano.

The University of Liège (Belgium), through its marine research station STARESO, operates a permanent sampling station (PHYTocly) in the western part of the bay. It is located close to the cape Revellata, which is a fully protected wilderness area.

\subsection{Sampling}

Sampling was conducted at the PHYTOcLY station and, on rare occasions, at the canyon head station (Fig. 1). The position of the Pнутосly station is $42^{\circ} 34.85^{\prime} \mathrm{N}, 08^{\circ} 43.71^{\prime} \mathrm{E}$, close to the $40 \mathrm{~m}$ isobath. In some cases, depending on meteorological conditions and/or boat availability, sampling was performed slightly closer to the shore $\left(42^{\circ} 34.85^{\prime} \mathrm{N}, 08^{\circ} 43.60^{\prime} \mathrm{E}\right)$, on the $10 \mathrm{~m}$ isobath. The two locations are $150 \mathrm{~m}$ from each other. Surface Total chl $a$ (Tchl $a$, i.e. chl $a+\operatorname{DVchl} a$, see below) and nitrate were sampled simultaneously at the two locations in winters of 1999 and 2009. The two combined data sets showed strong similarity between concentrations measured at the two locations, i.e. for $\mathrm{NO}_{3}$, $r^{2}=0.98(n=95)$, and for Tchl $a, r^{2}=0.99(n=79)$. Water depth at the canyon head station $\left(42^{\circ} 35.79^{\prime} \mathrm{N}, 08^{\circ} 44.770^{\prime} \mathrm{E}\right)$ is $155 \mathrm{~m}$.

Water samples were collected at the Pнутосьу station between 1979 and 2011. From 1979 to 2005, sampling was essentially conducted during the winter-spring period, with some interruptions because of non-continuous funding. From 2006 to 2011, data were 
acquired during the whole year. Sampling was performed at surface $(1 \mathrm{~m})$ with 2.5 -L Niskin bottles. The sampling time was 09:00 am (local time) between 1979 and 2002, and 07:00 am (local time) from 2005 onwards (no sampling in 2003 and 2004). Details on sampling frequencies are provided in Table 1 . In addition, water samples were collected at 4 to 9 depths between surface and bottom (i.e. $40 \mathrm{~m}$ ) on twenty occasions between January and June 1999. In the present study, we combine results from a total number of 1128 sampling dates.

Water samples for nutrient determinations $(20 \mathrm{ml})$ were frozen immediately in polyethylene flasks and stored at $-20^{\circ} \mathrm{C}$ until analysis. The flasks had previously been soaked in $10 \% \mathrm{HCl}$ for $24 \mathrm{~h}$, and rinsed three times first with Milli-Q water and then with the sampled water. Samples for chl $a$ analysis (1-5 L) were prefiltered through a $200 \mu \mathrm{m}$ mesh screen to remove mesozooplankton. They were immediately filtered under low vacuum pressure
( $<100 \mathrm{~mm} \mathrm{Hg}$ ) through Whatman GF/C filters (nominal pore size $1.2 \mu \mathrm{m}$ ) in 1979 and 1986, and through Whatman GF/F filters (nominal pore size $0.7 \mu \mathrm{m}$ ) from 1988 onwards. The filters were wrapped in aluminium foil and stored at $-20^{\circ} \mathrm{C}$. The use of GF/C filters during the first 2 time series may have resulted in an underestimation of chl $a$ concentration, but both GF/C and GF/F filters retain a higher proportion of small particles than could be expected from their nominal pore sizes. In a study carried out in the Northwestern Mediterranean, parallel measurements using GF/C and $0.4 \mu \mathrm{m}$ Nucleopore filters did not show significant differences (Estrada et al., 1993).

\subsection{Water temperature and CTD profiles}

Temperature at $3 \mathrm{~m}$ (hereinafter referred to as subsurface temperature) was measured $350 \mathrm{~m}$ to the west of the PнутосLу station

Table 1

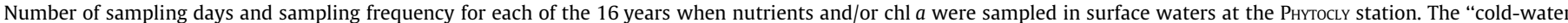
period" is the winter period during which subsurface water temperature was continuously $\leqslant 13.5^{\circ} \mathrm{C}$.

\begin{tabular}{|c|c|c|c|c|}
\hline \multirow[t]{2}{*}{$\begin{array}{l}\text { Sampling period (From December of } \\
\text { year } x-1 \text { to November of year } x \text { ) }\end{array}$} & \multicolumn{2}{|c|}{$\begin{array}{l}\text { Number of sampling days } \\
\text { during the cold-water } \\
\text { period/during the total } \\
\text { sampling period }\end{array}$} & \multicolumn{2}{|l|}{ Sampling frequency } \\
\hline & $\mathrm{NO}_{3}$ and $\mathrm{Si}(\mathrm{OH})_{4}$ & Tchl $a$ & $\mathrm{NO}_{3}$ and $\mathrm{Si}(\mathrm{OH})_{4}$ & Tchl $a$ \\
\hline 1979 & - & $15 / 22$ & - & 01/02-21/05: weekly \\
\hline 1986 & - & $32 / 62$ & - & 28/02-02/05: daily \\
\hline 1988 & $31 / 50$ & $30 / 48$ & $22 / 02-13 / 05:$ daily or every second day & $22 / 02-13 / 05:$ daily or every second day \\
\hline 1997 & $27 / 99$ & $25 / 89$ & $\begin{array}{l}\text { 03/01-09/01: weekly } \\
\text { 22/01-10/04: daily } \\
\text { 29/05-09/06: daily or every second day } \\
\text { 10-14/06: daily }\left(\mathrm{NO}_{3}\right) \\
\text { 29/05-09/06: daily }\left(\mathrm{Si}(\mathrm{OH})_{4}\right) \\
\text { 19/08-30/08: daily } \\
\text { 10-24/10: daily or every second day }\left(\mathrm{Si}(\mathrm{OH})_{4}\right)\end{array}$ & $\begin{array}{l}\text { 03/01-09/01: weekly } \\
\text { 22/01-10/04: daily } \\
\text { 29/05-09/06: daily or every second day } \\
\text { 25/08-30/08: daily } \\
\text { 14-22/10: daily or every second day }\end{array}$ \\
\hline 1998 & $20 / 102$ & $20 / 101$ & $\begin{array}{l}\text { 22/01-08/06: daily or every second day } \\
\text { 27-30/08: daily or every second day } \\
\text { 24-31/10: daily }\left(\mathrm{Si}(\mathrm{OH})_{4}\right)\end{array}$ & $\begin{array}{l}\text { 22/01-08/06: daily or every second day } \\
\text { 27-28/08: daily } \\
\text { 24-31/10: daily }\end{array}$ \\
\hline 1999 & $71 / 150$ & $56 / 115$ & $\begin{array}{l}\text { 18/01-19/05: daily } \\
\text { 25/05-29/06: daily } \\
\text { 05-16/11: } 2 \text { to } 3 \text { times per week }\end{array}$ & $\begin{array}{l}\text { 18/01-16/05: daily } \\
\text { 19/05-28/06: } 3 \text { times per week } \\
\text { 06-11/11: daily }\end{array}$ \\
\hline 2000 & $56 / 76$ & - & $\begin{array}{l}\text { 05-10/12: daily } \\
\text { 15-21/01: weekly } \\
\text { 04/02-30/03: daily } \\
\text { 07/04-20/04: every second day } \\
\text { 28/05-08/06: } 3 \text { times per week }\end{array}$ & - \\
\hline 2001 & $45 / 73$ & $32 / 57$ & $\begin{array}{l}\text { 23/01-16/03: daily or every second day } \\
\text { 29/03-11/05: monthly } \\
\text { 17/05-09/06: weekly } \\
\text { 25/09-04/10: daily } \\
\text { 10/10-22/11: weekly }\end{array}$ & $\begin{array}{l}\text { 24/01-16/03: daily or every second day } \\
\text { 22/03-01/06: weekly } \\
\text { 25/09-04/10: daily or every second day } \\
\text { 10/10-29/11: weekly }\end{array}$ \\
\hline 2002 & $11 / 21$ & $10 / 17$ & 05/12-11/04: weekly & 05/12-11/04: weekly \\
\hline 2005 & - & $5 / 38$ & & $\begin{array}{l}\text { 12/12-23/02: monthly } \\
\text { 04/03-01/04: weekly } \\
\text { 28/04-23/11: weekly }\end{array}$ \\
\hline 2006 & $21 / 70$ & $22 / 73$ & $\begin{array}{l}\text { 06/12-15/02: weekly } \\
\text { 21/02-29/11: } 1 \text { to } 3 \text { times per week }\end{array}$ & $\begin{array}{l}\text { 06/12-15/02: weekly } \\
\text { 21/02-04/07: } 1 \text { to } 3 \text { times per week } \\
\text { 11/07-29/11: weekly }\end{array}$ \\
\hline 2007 & $1 / 69$ & $1 / 70$ & $\begin{array}{l}\text { 05/12-22/05: } 2 \text { times per week } \\
\text { 31/05-14/06: daily }\left(\mathrm{NO}_{3}\right) \\
\text { 19/06-27/11: weekly }\end{array}$ & $\begin{array}{l}\text { 05/12-30/01: weekly } \\
\text { 02/02-22/05: } 2 \text { times per week } \\
\text { 31/05-14/06: daily } \\
\text { 19/06-27/11: weekly }\end{array}$ \\
\hline 2008 & $25 / 69$ & $25 / 70$ & $\begin{array}{l}\text { 05/12-19/02: weekly } \\
\text { 22/02-08/07: } 2 \text { times per week } \\
\text { 15/07-25/11: weekly }\end{array}$ & $\begin{array}{l}\text { 05/12-19/02: weekly } \\
\text { 22/02-08/07: } 2 \text { times per week } \\
\text { 15/07-25/11: weekly }\end{array}$ \\
\hline 2009 & $26 / 76$ & $25 / 74$ & $\begin{array}{l}\text { 02/12-06/01: weekly } \\
\text { 08/01-30/06: } 2 \text { times per week } \\
\text { 06/07-30/11: weekly }\end{array}$ & $\begin{array}{l}\text { 02/12-06/01: weekly } \\
\text { 08/01-30/06: } 2 \text { times per week } \\
\text { 06/07-30/11: weekly }\end{array}$ \\
\hline 2010 & $26 / 70$ & $28 / 71$ & $\begin{array}{l}\text { 08/12-12/01: weekly } \\
\text { 19/01-30/06: } 2 \text { times per week } \\
\text { 06/07-30/11: weekly }\end{array}$ & $\begin{array}{l}\text { 08/12-12/01: weekly } \\
\text { 19/01-30/06: } 2 \text { times per week } \\
\text { 06/07-30/11: weekly }\end{array}$ \\
\hline 2011 & $28 / 78$ & $28 / 79$ & $\begin{array}{l}\text { 03/12-28/06: } 2 \text { times per week } \\
\text { 04/07-28/11: weekly }\end{array}$ & $\begin{array}{l}\text { 03/12-28/06: } 2 \text { times per week } \\
\text { 04/07-28/11: weekly }\end{array}$ \\
\hline
\end{tabular}


(Fig. 1). It was recorded over the whole 32-year period (19792011), with one interruption between June 1979 and January 1980, hence a 31-year record. In 1979, 26 temperature measurements were performed at 09:00 am (local time) between January and May. From February 1980 to December 2011, measurements were performed daily at 09:00 am (local time) until December 2002, and at 08:00 UTC from January 2003. An underwater thermometer (precision: $\pm 0.1^{\circ} \mathrm{C}$ ) was used until 1996, which was replaced by an Aanderaa temperature sensor 3444 (precision: $\pm 0.02{ }^{\circ} \mathrm{C}$ ) from 1997 to 2011 . From 1989 onwards, temperature data were acquired by STARESo S.A.S. (Calvi, France). In 1999, 21 CTD profiles $(0-40 \mathrm{~m})$ were recorded with a Seabird SBE 19 to obtain the vertical structure of temperature and density at the PнYтосLY sampling station. On rare occasions, additional CTD profiles were recorded down to a maximum of $100 \mathrm{~m}$ at the canyon head station (Fig. 1). Following the practice in physical oceanography, water density at in situ temperature $\left(\rho_{t}\right)$ was transformed into $\sigma_{t}$ (i.e. $\rho_{t}-1000.00 \mathrm{~kg} \mathrm{~m}^{-3}$ ). The mixed layer depth was determined from $\sigma_{t}$ profiles as the depth where the difference with the $\sigma_{t}$ value at $5 \mathrm{~m}$ was $\Delta \sigma_{t}=0.05 \mathrm{~kg} \mathrm{~m}^{-3}$ (Levy et al., 1998).

\subsection{Cold-water period}

In this work, we define the "cold-water period" as the winter period during which subsurface water temperature was $\leqslant 13.5^{\circ} \mathrm{C}$. The boundaries of the cold-water period were fixed as follows: the cold-water period started the first day on which water temperature dropped below $13.5^{\circ} \mathrm{C}$ and was $\leqslant 13.5^{\circ} \mathrm{C}$ for at least one day, and ended the day from which increasing water temperature exceeded $13.5^{\circ} \mathrm{C}$ for at least one week.

\subsection{Wind data, wind events and winter intensity index (WII)}

Mean wind speed $\left(\mathrm{m} \mathrm{s}^{-1}\right)$ and mean wind direction (degrees calculated clockwise from the geographical north) were measured during $10 \mathrm{~min}$ every third hour at the Calvi airport by Méteo France, the French national weather organisation, under "FF" and "DD" denominations, respectively. They were recorded over the whole 1979-2011 period, with one interruption in both 1980 and 1981. Mean wind direction was recorded in $20^{\circ}$ increments until January 1988, and in $10^{\circ}$ increments from February 1988 onwards. We computed mean daily wind speed from the FF data set. Here we define a Wind Event as a day characterised by a mean daily wind speed $>5 \mathrm{~m} \mathrm{~s}^{-1}$. We calculated the frequency distribution of wind direction from the DD data set.

In the Mediterranean, the effect of strong winter winds on the mixed layer depth is high, and on surface temperature is very low (D'Ortenzio and Prieur, 2012). Hence wind intensity and winter water temperature are quite independent, and a long cold-water period is not necessarily the consequence of very windy conditions. This led us to define and calculate the following Winter Intensity Index (WII):

$\mathrm{WII}=(\mathrm{CW} \times \mathrm{WE}) / 1000$,

where $\mathrm{CW}$ is the duration (number of days) of the cold-water period, and WE is the number of wind events during the cold-water period. We considered that low $(<1.3)$, intermediate $(1.3-3.5)$ and high ( $>3.5)$ WII characterised mild, moderate and severe winters, respectively. We used WII as a proxy to assess the intensity of winter vertical mixing that could affect nutrient enrichment of surface waters.

\subsection{Nutrients and chl a determination}

Nutrients were determined using a Technicon AutoAnalyser II, within 3 months of sampling. Nitrate and nitrite were analysed according to working procedures of Tréguer and Le Corre (1975). Nitrate concentration was obtained by subtracting the corresponding nitrite value from the $\mathrm{NO}_{3}+\mathrm{NO}_{2}$ concentration. The analytical limits of detection (two times the standard deviation of the blank) were $0.02 \mu \mathrm{M}$ and $0.01 \mu \mathrm{M}$ for $\mathrm{NO}_{3}$ and $\mathrm{NO}_{2}$, respectively. Silicate in samples collected in 1988 and from 1997 to 2011 was determined according to Atlas et al. (1971) and Gordon et al. (1993), respectively. The analytical limit of detection was $0.05 \mu \mathrm{M}$. To ensure the reproducibility of nutrient measurements among different sampling periods, in-house standards were employed, which were regularly compared to the commercially available products (OSIL marine nutrient standards).

Protocols used for chl $a$ determination are summarised in Table 2. Changes in extraction, separation and quantification

Table 2

Methods used for Tchl $a$ extraction and determination between 1979 and 2011

\begin{tabular}{|c|c|c|c|c|c|c|}
\hline $\begin{array}{l}\text { Year (from December of year } x-1 \text { to } \\
\text { November of year } x \text { ) }\end{array}$ & $\begin{array}{l}\text { Whatman } \\
\text { filters }\end{array}$ & $\begin{array}{l}\text { Volume } \\
\text { filtered (L) }\end{array}$ & Method & $\begin{array}{l}\text { Extraction } \\
\text { solvent (\%) }\end{array}$ & Extraction reference & Analysis reference \\
\hline 1979 & $\mathrm{GF} / \mathrm{C}$ & 5 & Spectrophotometric & 90 acetone & Goffart (1992) & SCOR-UNESCO (1966) \\
\hline 1986 & $\mathrm{GF} / \mathrm{C}$ & 2 & Spectrophotometric & 90 acetone & Goffart (1992) & Lorenzen (1967) \\
\hline 1988 & $\mathrm{GF} / \mathrm{F}$ & 2 & HPLC, RP-C18 & 100 methanol & Goffart (1992) & $\begin{array}{l}\text { Mantoura and } \\
\text { Llewellyn (1983) }\end{array}$ \\
\hline 1997 & $\mathrm{GF} / \mathrm{F}$ & 2 & HPLC, RP-C18 & 100 methanol & $\begin{array}{l}\text { Williams and Claustre } \\
\text { (1991) }\end{array}$ & $\begin{array}{l}\text { Williams and Claustre } \\
\text { (1991) }\end{array}$ \\
\hline 1998 & $\mathrm{GF} / \mathrm{F}$ & 2 & HPLC, RP-C18 & 100 methanol & $\begin{array}{l}\text { Williams and Claustre } \\
\text { (1991) }\end{array}$ & $\begin{array}{l}\text { Williams and Claustre } \\
\text { (1991) }\end{array}$ \\
\hline 1999 & $\mathrm{GF} / \mathrm{F}$ & 1 & HPLC, RP-C18 & 100 methanol & $\begin{array}{l}\text { Bustillos-Guzmán } \\
\text { et al. (1995) }\end{array}$ & $\begin{array}{l}\text { Williams and Claustre } \\
\text { (1991) }\end{array}$ \\
\hline 2001 & $\mathrm{GF} / \mathrm{F}$ & 1 & HPLC, RP-C18 & 100 methanol & Vidussi et al. (2000) & $\begin{array}{l}\text { Williams and Claustre } \\
\text { (1991) }\end{array}$ \\
\hline 2002 & $\mathrm{GF} / \mathrm{F}$ & 1 & HPLC, RP-C18 & 100 methanol & Vidussi et al. (2000) & $\begin{array}{l}\text { Williams and Claustre } \\
\text { (1991) }\end{array}$ \\
\hline 2005 & $\mathrm{GF} / \mathrm{F}$ & 1 & HPLC, RP-C18 & 100 methanol & Vidussi et al. (2000) & $\begin{array}{l}\text { Williams and Claustre } \\
\text { (1991) }\end{array}$ \\
\hline 2006 & $\mathrm{GF} / \mathrm{F}$ & 1 & HPLC, RP-C18 & 100 methanol & Vidussi et al. (2000) & $\begin{array}{l}\text { Williams and Claustre } \\
\text { (1991) }\end{array}$ \\
\hline 2007 & $\mathrm{GF} / \mathrm{F}$ & 1 & HPLC, RP-C8 & 100 methanol & Vidussi et al. (2000) & Zapata et al. (2000) \\
\hline 2008 & $\mathrm{GF} / \mathrm{F}$ & 1 & HPLC, RP-C8 & 100 methanol & Vidussi et al. (2000) & Zapata et al. (2000) \\
\hline 2009 & $\mathrm{GF} / \mathrm{F}$ & 1 & HPLC, RP-C8 & 100 methanol & Vidussi et al. (2000) & Zapata et al. (2000) \\
\hline 2010 & $\mathrm{GF} / \mathrm{F}$ & 1 & HPLC, RP-C8 & 100 methanol & Vidussi et al. (2000) & Zapata et al. (2000) \\
\hline 2011 & $\mathrm{GF} / \mathrm{F}$ & 1 & HPLC, RP-C8 & 100 methanol & Vidussi et al. (2000) & Zapata et al. (2000) \\
\hline
\end{tabular}


techniques were the result of the considerable advances in analytical procedures that occurred since 1979. Comparison of chl $a$ measured by spectrophotometric techniques and determined by HPLC is given in Goffart et al. (2002). The possible effect of changes of methods was tested by analysing series of samples with successive procedures. The agreement between successive methods was good for chl $a$, showing the continuity of the data set. As the resolution between divinyl-chl $a$ (DVchl $a$ ) and chl $a$ was not achieved by the methods used between 1979 and 2006, results are reported here in term of Total chl $a$ (Tchl $a=\operatorname{chl} a+$ DVchl $a$ ). Standards purchased from DHI were used for calibration. Tchl $a$ was analysed within 3 months of sampling.

\subsection{Characteristics of nutrient and phytoplankton time series}

Time series of nutrients and Tchl $a$ were selected for numerical analyses based on the length and completeness of each data record, i.e. each selected series for a given year had to cover the entire cold-water period that year. For the earliest records $(1979,1986$, 1988 and 1997) from which nutrient and phytoplankton values were missing at the beginning of the cold-water period, we relaxed this criterion, i.e. the maximum gap in the data we accepted was 36 days, which occurred in 1986. Based on this selection criterion, we kept nutrient and phytoplankton time series for 13 and 15 years, respectively (Table 3 ). The complete nutrient and phytoplankton biomass time series, as well as the 1999 vertical profiles, are available at http://doi.pangaea.de/10.1594/PANGAEA.832874 and http://dx.doi.org/10.1594/PANGAEA.846507 as online supporting material.

\subsection{Integrated and mean concentrations over the cold-water period}

Concentrations of $\mathrm{NO}_{3}, \mathrm{Si}(\mathrm{OH})_{4}$ and Tchl $a$ at $1 \mathrm{~m}$ depth were time-integrated over the cold-water period with the usual rectangle method (i.e. midpoint rule). When the first data point at the beginning of the cold-water period was missing, and no data was available during the previous weeks, typical late autumn values for the different variables were assigned to the first day of the cold-water period: these default values were $0.1 \mu \mathrm{M}$ for $\mathrm{NO}_{3}$, $0.6 \mu \mathrm{M}$ for $\mathrm{Si}(\mathrm{OH})_{4}$, and $0.1 \mu \mathrm{g} \mathrm{L}^{-1}$ for Tchl $a$. The total concentrations of $\mathrm{NO}_{3}, \mathrm{Si}(\mathrm{OH})_{4}$ and Tchl $a$ in surface water over the cold-water period were divided by the duration (number of days) of the latter to obtain mean cold-water period concentrations.

\section{Results}

\subsection{Winter-spring pattern, with a focus on 1999}

Results in this section focus on seasonal changes in water-column structure and the corresponding changes in temperature, $\mathrm{NO}_{3}, \mathrm{Si}(\mathrm{OH})_{4}$ and Tchl $a$ near the surface at station PнҮтосLY from mid-January to late June 1999. This dataset is unique in the 1979-2011 period of observation in that daily surface measurements were accompanied by weekly vertical profiles. In addition, a limited number of vertical profiles of temperature and $\sigma_{t}$ acquired in other years at the canyon head station are presented for comparison.

\subsubsection{Physical characteristics}

In 1999, based on daily changes in subsurface water temperature at station Phyтосly, the cold-water period $\left(\leqslant 13.5^{\circ} \mathrm{C}\right)$ started on 09 January and ended on 01 April (Table 3 and Fig. 2A). Seasonal changes in the vertical distributions of temperature and $\sigma_{t}$ at that station show a clear transition from winter to late spring (Fig. 3). As long as the subsurface water temperature was $\leqslant 13.0^{\circ} \mathrm{C}$,

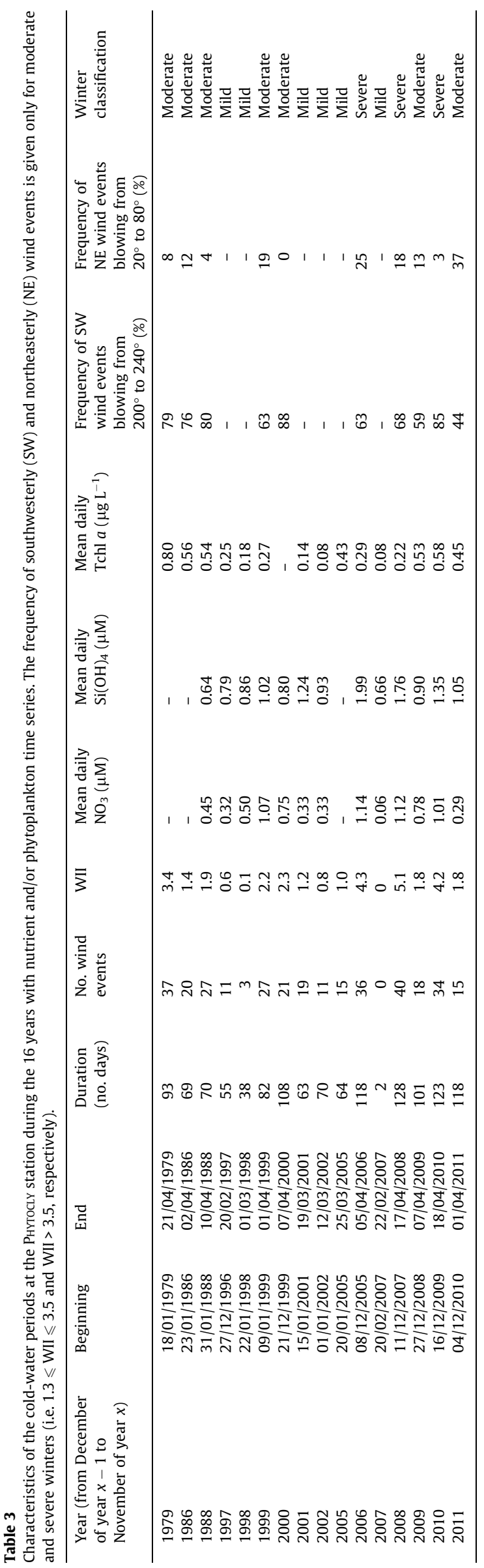



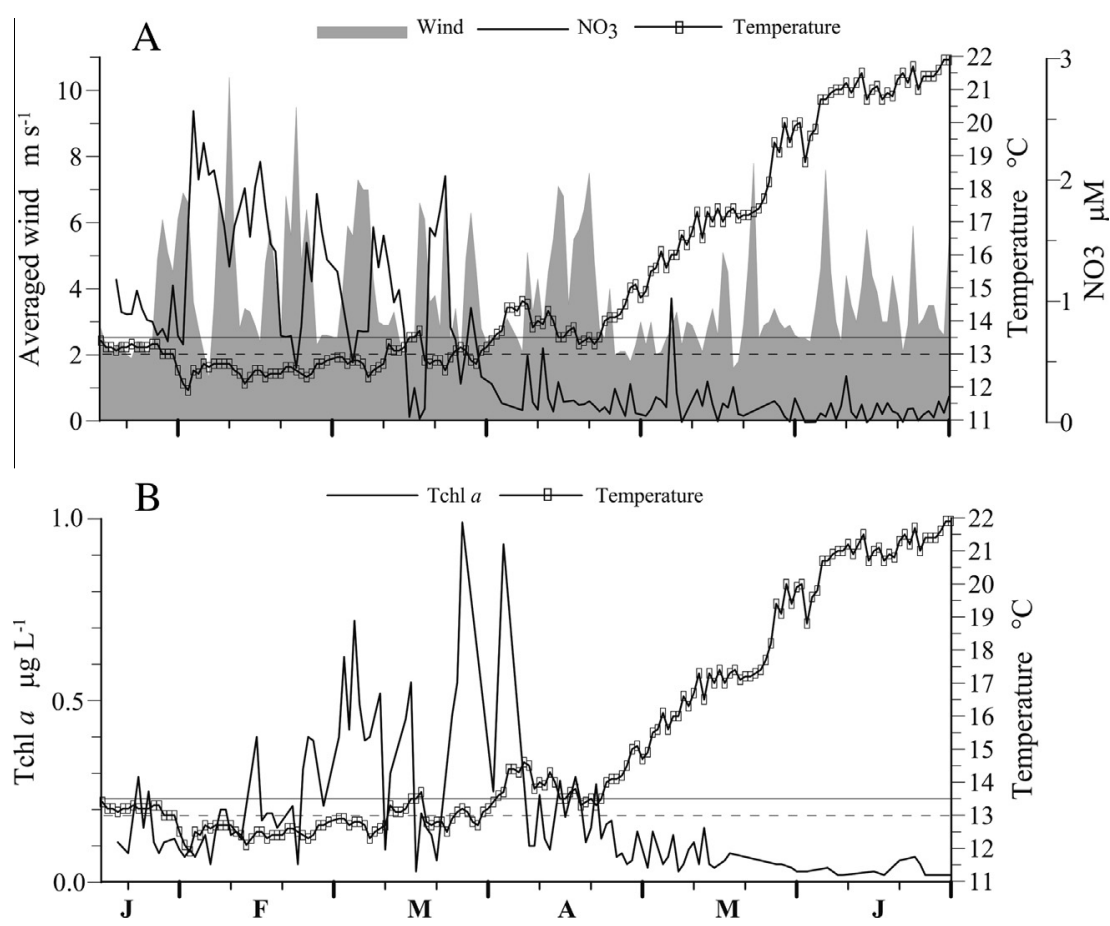

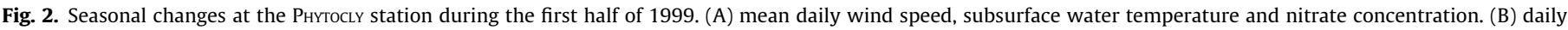

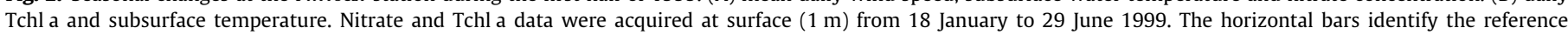
temperature values of 13.0 and $13.5^{\circ} \mathrm{C}$.

the whole water column was well mixed. When subsurface water temperature increased from $>13.0$ to $\leqslant 13.5^{\circ} \mathrm{C}$, the $\sigma_{t}$ difference between 5 and $40 \mathrm{~m}$ also increased, from 0.00 to $0.09 \mathrm{~kg} \mathrm{~m}^{-3}$. After reaching $14.0^{\circ} \mathrm{C}$ at the end of April, surface waters warmed rapidly and their $\sigma_{t}$ decreased correspondingly, resulting in the establishment of a pronounced pycnocline and thus in a significant increase in water-column stability.

When available, vertical profiles of temperature and $\sigma_{t}$ at the canyon head station show that when subsurface water temperature was $\leqslant 13.0^{\circ} \mathrm{C}$, the water column was well mixed and the mixed layer extended deeper than the immersion depth of the CTD (60-85 $\mathrm{m})$, indicating that the density difference between 0 and $60 \mathrm{~m}\left(\Delta \sigma_{t} 0_{-60}\right)$ was $\approx 0.00 \mathrm{~kg} \mathrm{~m}^{-3}$ (Fig. 4). When subsurface temperature was $>13.5^{\circ} \mathrm{C}$ and $<14.0^{\circ} \mathrm{C}, \Delta \sigma_{t}$ 0-60 was $0.35 \mathrm{~kg} \mathrm{~m}^{-3}$. After the subsurface temperature reached $14.0^{\circ} \mathrm{C}, \Delta \sigma_{t 0-60}$ and the mixed layer thickness were directly and inversely proportional, respectively, to subsurface water temperature. By the end of May, the summer thermocline was well established and ranged between 20 and $40 \mathrm{~m}$. The water column remained strongly stratified until late October (data not shown).

\subsubsection{Nutrients}

In 1999, surface $\mathrm{NO}_{3}$ concentrations at station PHYTOCLY were highly variable during the cold-water period, ranging from 2.57 to $0.03 \mu \mathrm{M}$, in January and March, respectively (Fig. 2A). Close examination of the $\mathrm{NO}_{3}$ and wind records show that nitrate covaried with wind intensity with a time lag of a few days (Fig. 2A). Each episode of continuously strong wind (mean daily wind speed $>5 \mathrm{~m} \mathrm{~s}^{-1}$ ) was followed by a sharp $\mathrm{NO}_{3}$ increase within 2-3 days. After the cold-water period had ended, i.e. after the beginning of April, $\mathrm{NO}_{3}$ concentrations declined and remained at constantly low or very low levels $(<0.02$ to $0.61 \mu \mathrm{M})$, with the exception of the one-day $1.02 \mu \mathrm{M}$ peak on 5 May, with no relationship between $\mathrm{NO}_{3}$ concentrations and wind events anymore.

From mid-January to late June 1999, the vertical distributions of $\mathrm{NO}_{3}$ were homogenous from surface to bottom (data not shown), so that surface and mean depth-integrated concentrations were very similar and linearly related $\left(r^{2}=0.90\right)$. Surface $\mathrm{Si}(\mathrm{OH})_{4}$ concentrations exhibited the same general pattern as nitrate, with some exceptions during very rainy days when small amounts of silicate from the granitic bedrock were sometimes introduced into the surface layer by freshwater runoff.

\subsubsection{Phytoplankton biomass (Tchl a)}

Surface phytoplankton biomass (Tchl $a$ ) at station PнyтосLY started to increase by mid-February, when subsurface water temperature was still $\leqslant 13.0^{\circ} \mathrm{C}$ (Fig. 2B). It reached a maximum value of $0.99 \mu \mathrm{g} \mathrm{L}^{-1}$ on 25 March, i.e. at the end of the cold-water period, and decreased very rapidly in early April. The phytoplankton bloom was plurimodal, with a succession of peaks and troughs.

Our 1999 observations showed that the bloom extended over the whole water column, and was homogenously distributed down to the bottom (Fig. 3D). In a first phase (from mid-February to mid-March), Tchl $a$ developed for about 4 weeks in a homogenous water column, when subsurface water was $\leqslant 13.0^{\circ} \mathrm{C}$ (Fig. $3 \mathrm{~A}$ and $\mathrm{B}$ ). In a second phase (from mid-March to the beginning of April), as winter progressively gave way to spring, Tchl $a$ continued to increase for $2-3$ weeks in conditions where vertical mixing alternated with some stability. The transition from the first to the second phase corresponded to a small increase in subsurface water temperature above the $13.0{ }^{\circ} \mathrm{C}$ threshold, with a temporary reduction in the depth of the mixed layer. It was followed by positive and negative variations around the $13.0^{\circ} \mathrm{C}$ threshold (Fig. 3C), which corresponded to a succession of fully mixed and more stable conditions, respectively. In a third, final phase (from the beginning of April onwards), the bloom collapsed abruptly when the cold-water period ended and that subsurface water temperature increased above $13.5^{\circ} \mathrm{C}$, leading to a marked increase in the occurrence of very stable conditions.

From mid-January to late June, mean depth-integrated and surface values were very similar and linearly related $\left(r^{2}=0.91\right)$. 

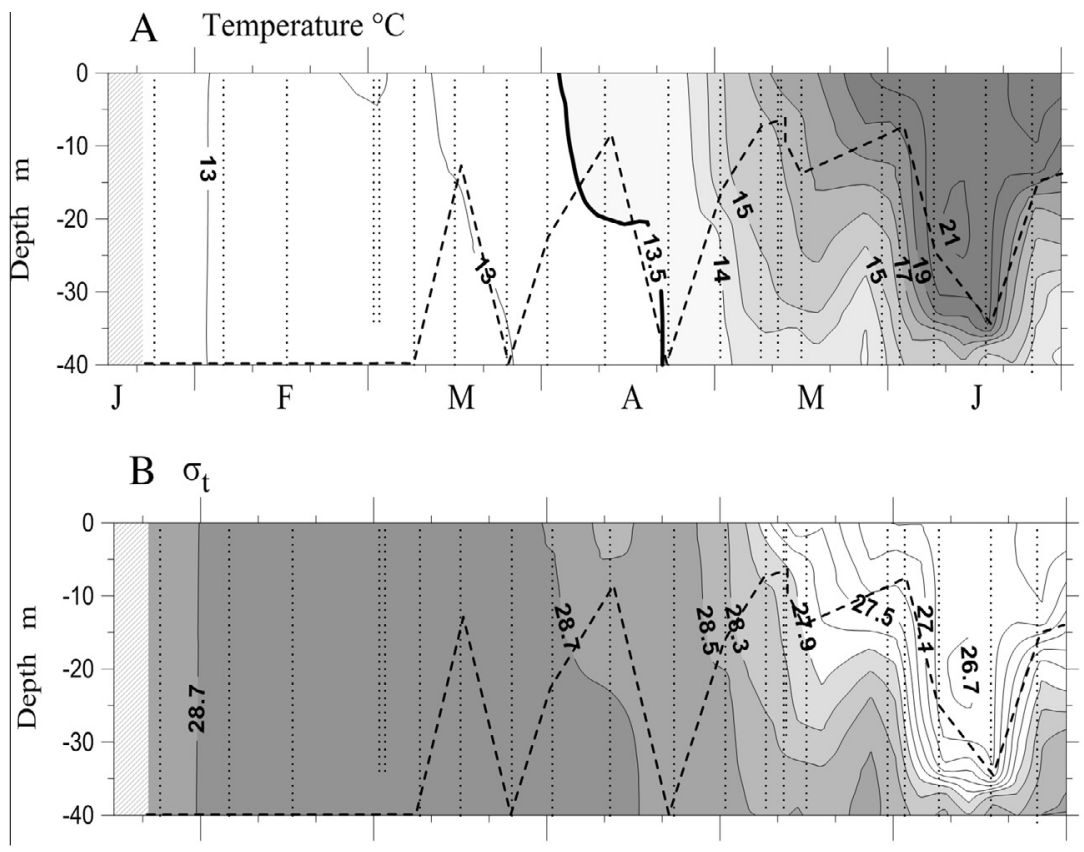

C Subsurface temperature ${ }^{\circ} \mathrm{C}$

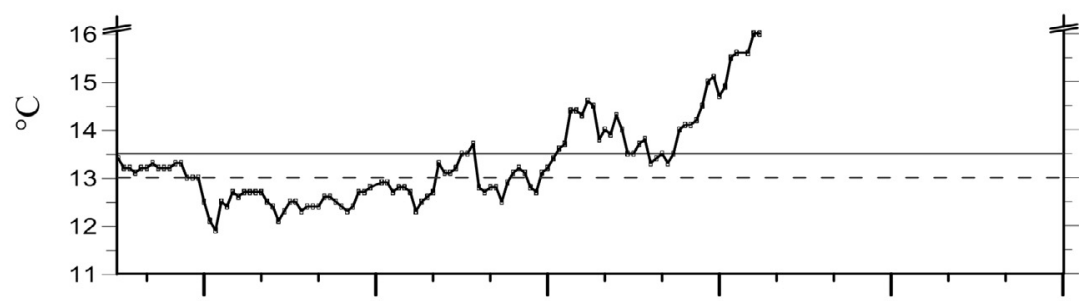

D Tchl $a \mu \mathrm{g} \mathrm{L}^{-1}$

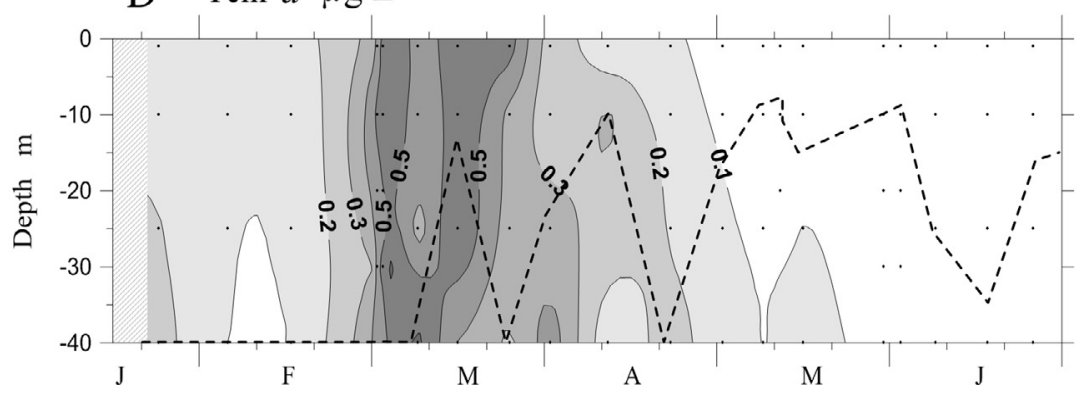

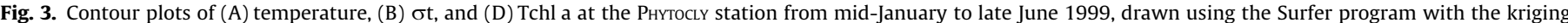

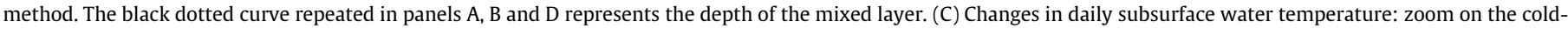
water period; the horizontal bars identify the reference temperature values of 13.0 and $13.5{ }^{\circ} \mathrm{C}$.

\subsection{Interannual variability}

\subsubsection{Water temperature}

During the whole 1979-2011 period, seasonal variations of subsurface water temperature followed a classical sinusoidal pattern, with minimum and maximum values during February (monthly average $13.0 \pm 0.7^{\circ} \mathrm{C}$ ) and August (monthly average $24.6 \pm 1.2^{\circ} \mathrm{C}$ ), respectively (Fig. 5A). Similarly, during years when there were nutrient and/or phytoplankton time series (Table 3), the coldest and warmest months were February (monthly average $12.8 \pm 0.6^{\circ} \mathrm{C}$ ) and August (monthly average $24.2 \pm 1.1^{\circ} \mathrm{C}$ ), respectively (Fig. 5B). Between 1979 and 2011, the lowest value $\left(11.2^{\circ} \mathrm{C}\right)$ was recorded in February 2010 and the highest $\left(26.6^{\circ} \mathrm{C}\right)$ in July of the same year.

The timing and duration of the cold-water period varied from year to year (Table 3 ). On the one hand, the beginning of the cold-water period varied from early December to late February in winters 2011 and 2007, respectively. On the other hand, the duration of the cold-water period varied from 2 to 128 days in winters 2007 and 2008, respectively.

\subsubsection{Wind}

In years when there were nutrient and/or phytoplankton time series at station Pнутосцу, the number of wind events during the cold-water period varied from 0 to 40 in winters 2007 and 2008, respectively (Table 3 ). There was an overall positive relationship between the number of wind events during the cold-water period and the duration of the latter $\left(r^{2}=0.74\right)$, but long cold-water periods did not always contain high numbers of wind events. For example, the cold-water period lasted 118 days in winters of both 2006 and 2011, but the first winter was extremely windy (36 wind events) whereas the second was characterised by weak winds with 


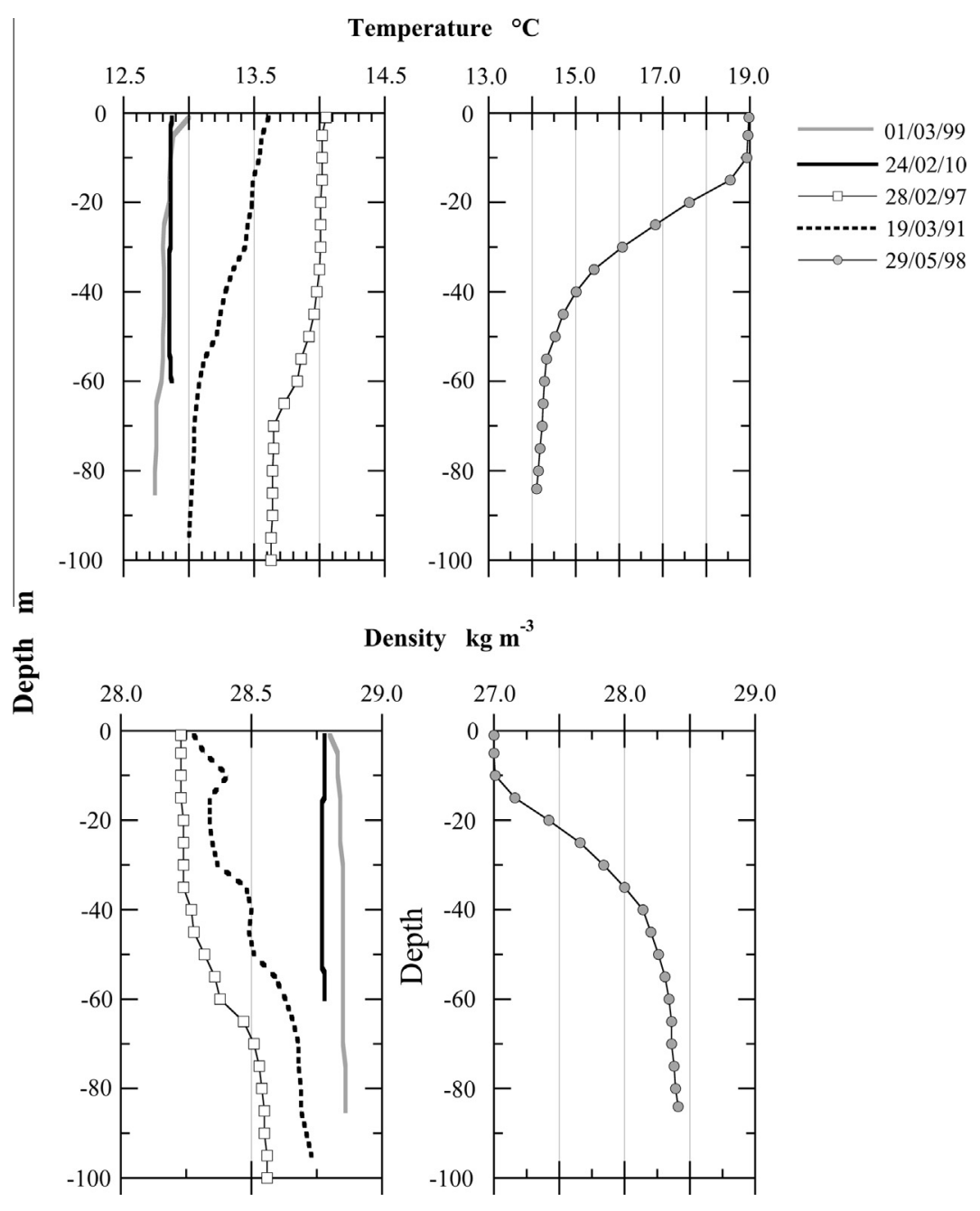

Fig. 4. Vertical profiles of temperature and $\sigma \mathrm{t}$ at the canyon head station during the winter-spring period. The profiles were recorded in different years.

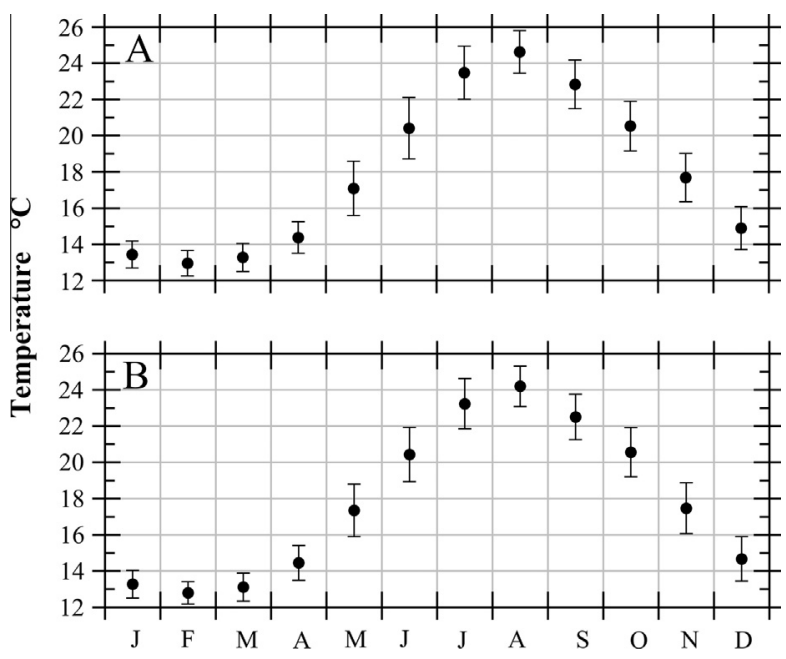

Fig. 5. Seasonal cycle of monthly subsurface water temperature: average values and standard deviations. (A) whole 1979-2011 period; (B) 16 years with nutrient and/or Tchl $a$ time series (Table 1 ).

only 15 wind events. Wind events were scattered through the cold-water periods, with the exception of three windless periods that lasted about 3 weeks in January-February 1997 and March 2000 and about 4 weeks in February 2011.
During the 1979-2011 period, the prevailing direction of wind events during the cold-water periods was southwesterly, with Libeccio blowing from $200^{\circ}$ to $240^{\circ}$ most of the time (Fig. 6A). Northeasterly wind events, blowing from $20^{\circ}$ to $80^{\circ}$, occurred regularly but were much less frequent. In years when there were nutrient and/or phytoplankton time series at station PHYTocly, wind direction during wind events of the cold-water periods was similar to that of the whole 1979-2011 period (Fig. 6B). During moderate and severe winters (WII $\geqslant 1.3$ ), the frequency of northeasterly wind events during the cold-water period ranged between 0 and $13 \%$ in 1979, 1986, 1988, 2000, 2009 and 2010 and between 18\% and 37\% in 1999, 2006, 2008 and 2011 (Table 3 and Fig. 6C and D).

There was high variability in WII among years when there were nutrient and phytoplankton time series at station Рнутосьу (Table 3). There was an almost decadal, long-term variability in WII, with three distinct periods: the 1980s (until 1988), the 1990s (1989-1998) and the 2000s (1999-2011), which were characterised by moderate, mild and highly variable winters, respectively (Fig. 7).

\subsubsection{Surface nutrients}

Values in the 13 time series of surface nutrient concentrations at station Pнутосly ranged between $<0.02$ and $3.89 \mu \mathrm{M}$ for $\mathrm{NO}_{3}$ and $<0.05$ and $4.24 \mu \mathrm{M}$ for $\mathrm{Si}(\mathrm{OH})_{4}$, and the high $\mathrm{NO}_{3}$ concentrations occurred during cold-water periods (e.g. 1999, 2008, 2010) (Fig. 8). Nitrate showed two contrasting patterns, which occurred 

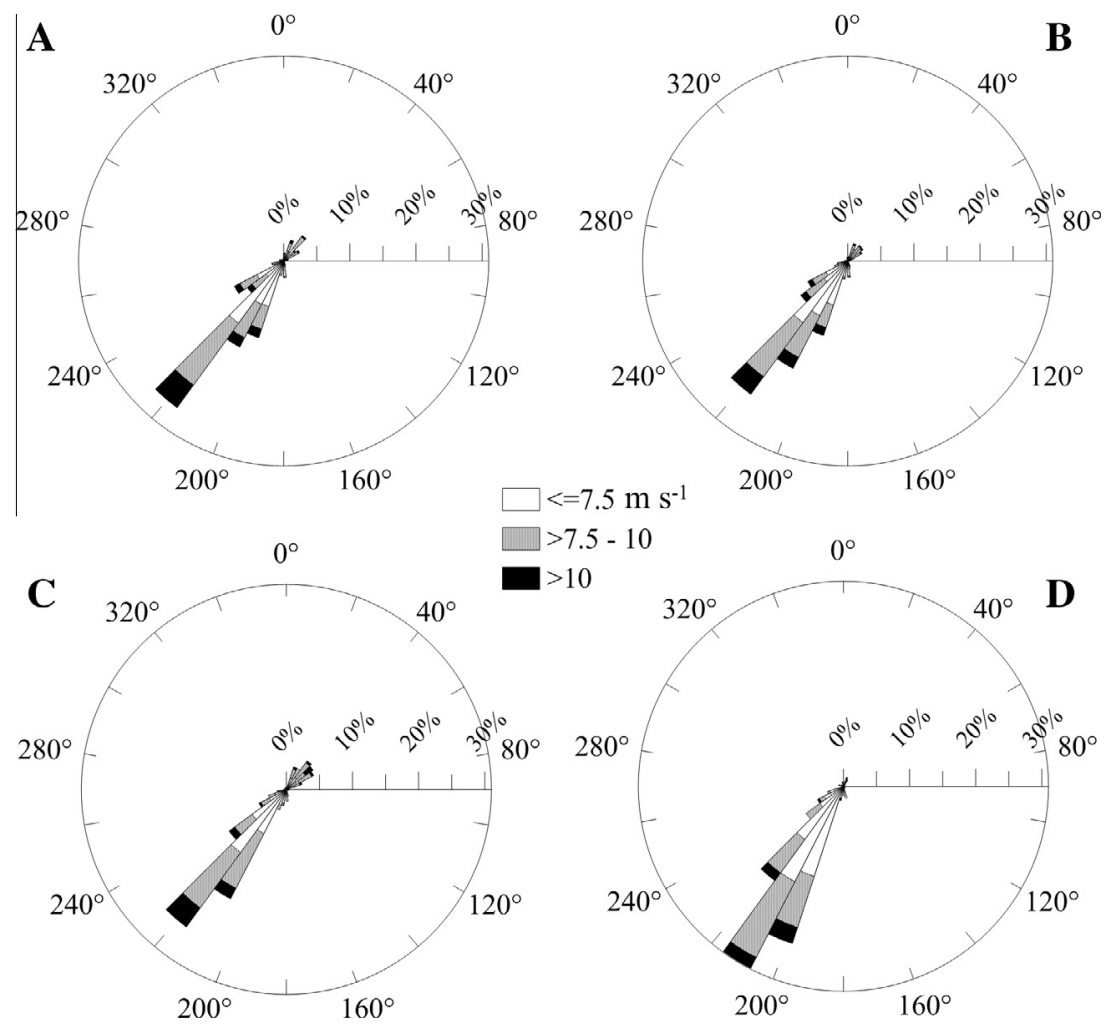

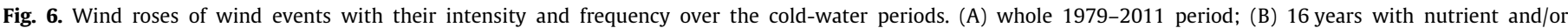

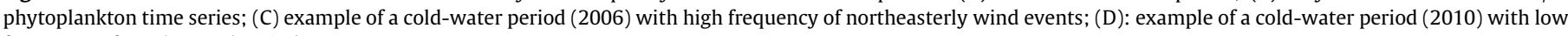
frequency of northeasterly wind events.

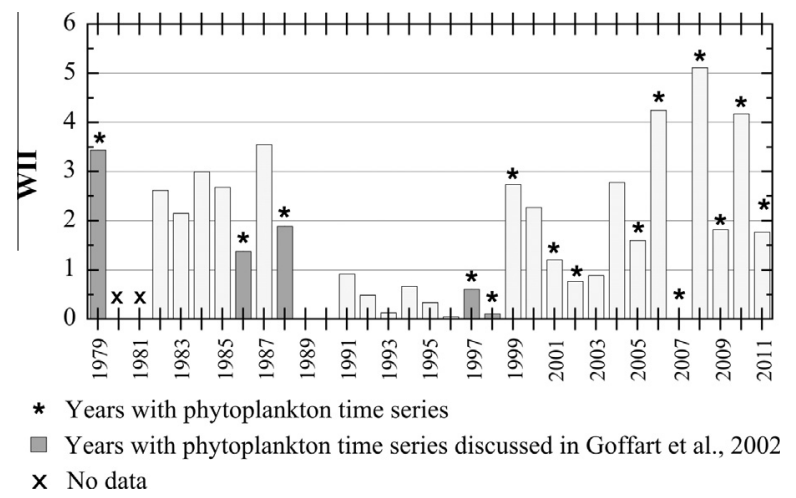

Fig. 7. Changes in the Winter Intensity Index (WII) during the 1979-2011 period.

repeatedly over the years although with high interannual variability. In the first pattern, $\mathrm{NO}_{3}$ was very low and quite constant throughout the year (e.g. 1997, 2007), and in the second, there was a large difference between the winter maximum and the following summer minimum (e.g. 1999, 2010). Only 2006 differed slightly from these two patterns, with high nitrate (1.20$2.51 \mu \mathrm{M}$ ) detected after the end of the cold-water period. The same general patterns were observed for silicate (data not shown), with some additional peaks observed after major rain events.

Mean daily nitrate and silicate concentrations during each cold-water period (Table 3 ) provide estimates of the pools of nutrients in surface waters during the period of the year when phytoplankton could bloom. Interannual variability was very high, i.e. values ranged from 0.06 to $1.14 \mu \mathrm{M}$ for $\mathrm{NO}_{3}$, and 0.64 to $1.99 \mu \mathrm{M}$ for $\mathrm{Si}(\mathrm{OH})_{4}$.

Although WII was highly variable over the 1979-2011 period (Table 3 and Fig. 7), plots of nutrients averaged over the cold-water periods as function of WII (Fig. 9) shows highly significant linear relationships between the variables $\left(\mathrm{NO}_{3}, r=0.85\right.$, $\left.n=13, p=0.0002 ; \mathrm{Si}(\mathrm{OH})_{4}, r=0.81, n=13, p=0.0007\right)$. The pool of nutrients was low during mild winters characterised by low WII (e.g. 1997, 2007), and high during severe winters characterised by high WII. The largest nutrient pool was recorded in winter 2006, with mean daily $\mathrm{NO}_{3}$ and $\mathrm{Si}(\mathrm{OH})_{4}$ values of $1.14 \mu \mathrm{M}$ and $1.99 \mu \mathrm{M}$, respectively.

\subsubsection{Surface phytoplankton biomass}

Between 1979 and 2011, surface Tchl $a$ concentrations ranged from undetectable to $1.88 \mu \mathrm{g} \mathrm{L}^{-1}$. The 15 time series showed large interannual variability in phytoplankton biomass, i.e. years with and without a winter-spring phytoplankton bloom (Fig. 10). In years with blooms (e.g. 1979, 1999, 2009), increases in biomass always occurred during the cold-water period. The timing of the annual maximum changed with years, i.e. it occurred between the middle and the end of the cold-water period. A shift of 6 weeks was observed between the earliest occurrence of the annual maximum (on 8 February in 2011) and the latest (25 March in 1999). The bloom started to decline between the second half and the end of the cold-water period depending on the year, and always collapsed when the subsurface water temperature exceeded $13.5^{\circ} \mathrm{C}$. As for mean $\mathrm{NO}_{3}$ and $\mathrm{Si}(\mathrm{OH})_{4}$ above, mean Tchl $a$ computed over each cold-water period varied widely, with values ranging between $0.08 \mu \mathrm{g} \mathrm{L}^{-1}$ in 2002 and 2007 and $0.80 \mu \mathrm{g} \mathrm{L}^{-1}$ in 1979 (Table 3).

The plot of average Tchl $a$ during the cold-water period as a function of WII (Fig. 9) shows that Tchl $a$ was strongly related to WII, but not linearly $(r=0.75, n=15, p=0.0244)$. Indeed, during years with mild and moderate winters (WII $\leqslant 3.5)$ Tchl $a$ increased with increasing WII, whereas in years with severe winters (WII > 3.5) Tchl $a$ decreased with increasing WII. 

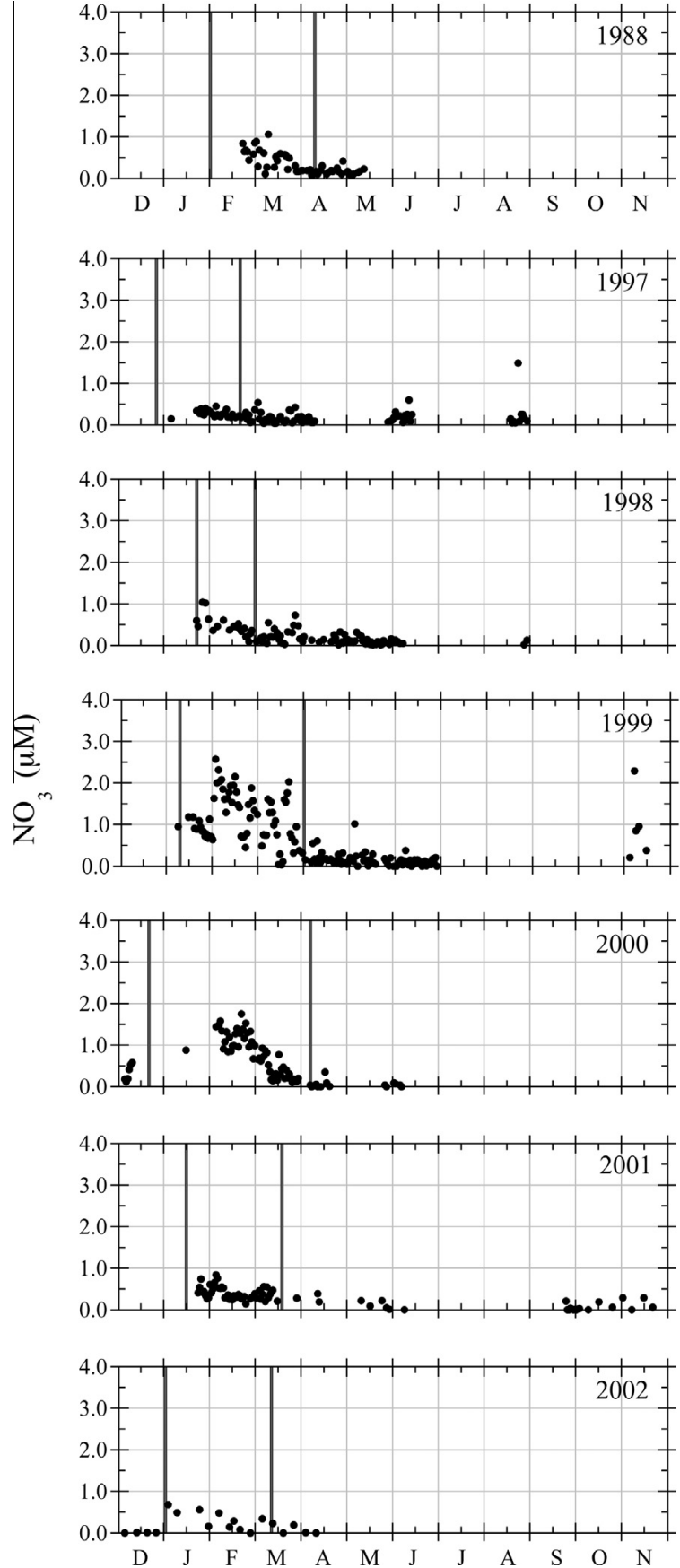
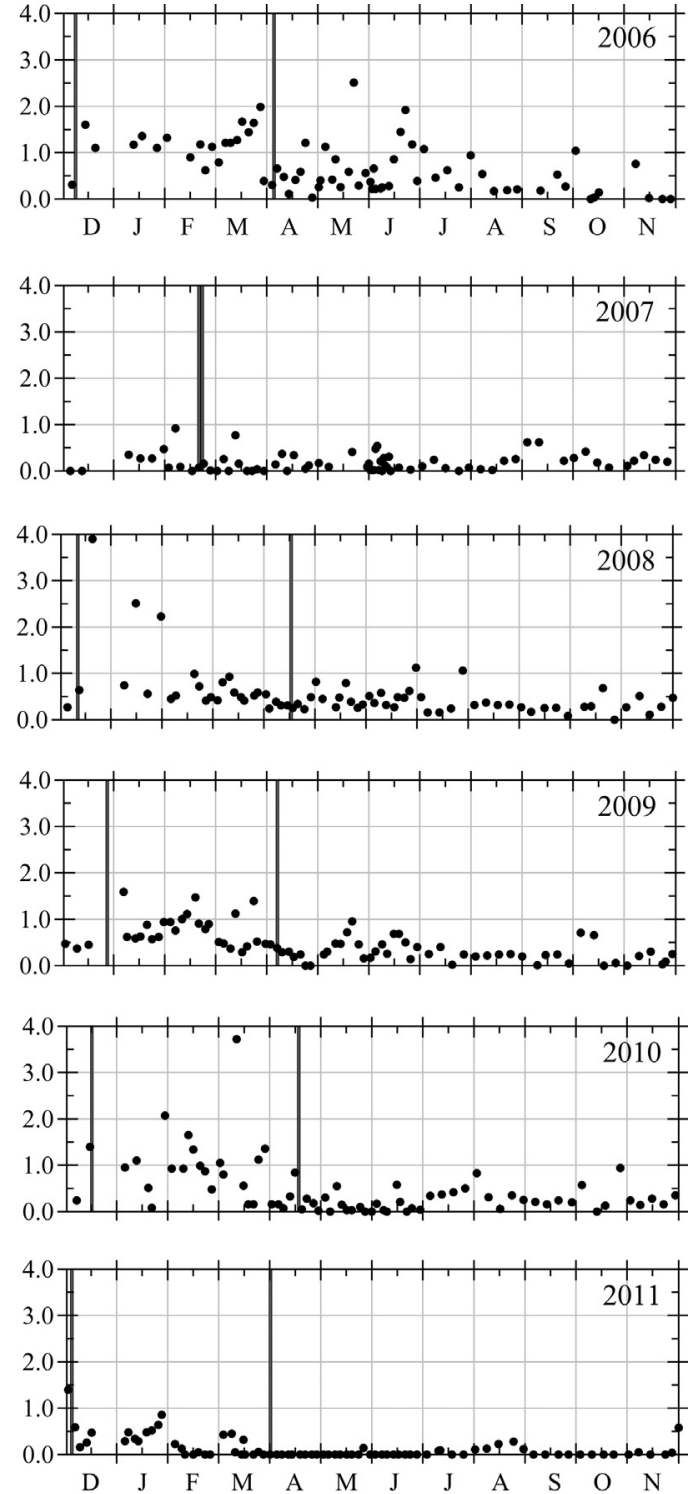

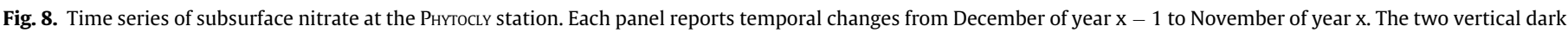
bars identify the limits of the cold-water periods $\left(\leqslant 13.5^{\circ} \mathrm{C}\right)$.

\section{Discussion}

In years when there were nutrient and chl $a$ time series at station Pнутосцу, samples were collected at frequencies that ranged from daily to biweekly during the winter-spring period (Table 1). This relatively high sampling frequency could capture short-term environmental and phytoplankton variability, which is outside the observational window of the more usual fortnightly or monthly time series. Moreover, because the Pнутосьу station is in direct connection with the open sea but close enough to the coast to be accessible by small boats, our results include data that describe phytoplankton responses to bad weather conditions, which are often lacking from long-term studies.

\subsection{Water temperature thresholds during the winter-spring period}

In the Western Mediterranean Sea, the general west-to-east gradient of increasing surface temperature makes difficult the direct comparison of different areas. Nevertheless, the annual pattern of subsurface water temperature in the Bay of Calvi during the 1979-2011 period was in good agreement with patterns reported for the coastal zones of the Balearic (Duarte and Agustí, 2004) and Ligurian (Gómez and Gorski, 2003) basins. In particular, variations were similar to those reported for the Bay of Villefranche-sur-Mer (Fig. 1A) during the 1979-1999 period, where the lowest values were recorded in February-March 

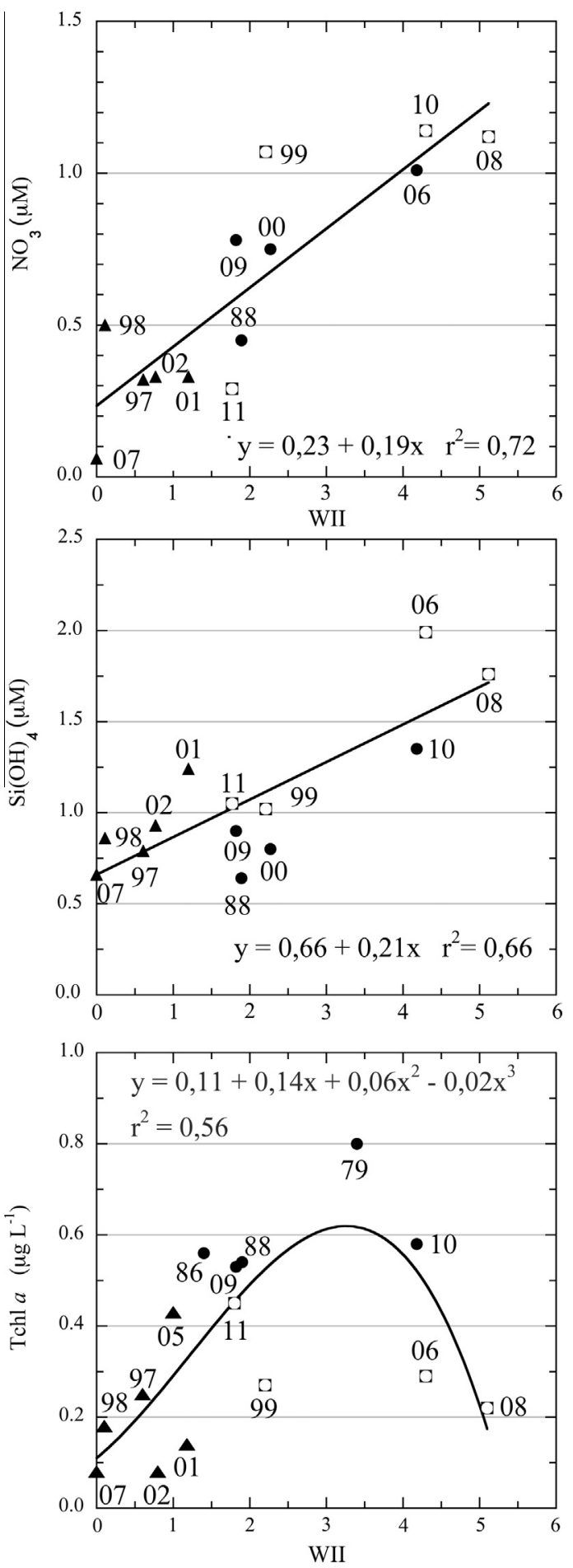

Fig. 9. Scatter diagrams of mean subsurface nutrients and Tchl $a$ during the coldwater periods as a function of the Winter Intensity Index (WII). Numbers near the dots refer to years. Triangles: years with $\mathrm{WII}<1.3$; filled circles and open squares: years with WII $\geqslant 1.3$. Filled circles and open squares: years during which the frequency of northeasterly wind events during the cold-water period was $\leqslant 13 \%$ and $>13 \%$, respectively.

(monthly averages $13.3-13.4 \pm 0.4^{\circ} \mathrm{C}$ ) and the highest in August (monthly average $24.3 \pm 0.8^{\circ} \mathrm{C}$ ) (Licandro et al., 2006).

In the offshore Western Mediterranean Sea, the mean winter temperature has been reported to vary among years in both surface waters (Skliris et al., 2011) and the 0-200 m layer (Marty and Chiavérini, 2010), and the analysis of a nine-year data set from the Ligurian and Balearic basins showed that the mean surface winter temperature (January-March) ranged from $\approx 12.5$ to $14.5^{\circ} \mathrm{C}$ (Santoleri et al., 1994). Few studies only have focused on changes in winter temperature in the shallow and coastal waters of the western basin. Zingone et al. (2010) and Vandromme et al. (2011) reported the occurrence of cold and warm winters, but no increasing or decreasing trend with time was detected in mean surface temperature from December to March over the 19852006 period (Nykjaer, 2009). Most of the studies in coastal areas have been devoted to changes in marine biota attributed to increasing summer temperatures. They included changes in distribution of thermophilic species (e.g. Francour et al., 1994), or mortality episodes caused by exceptional high summer temperatures (e.g. Cerrano et al., 2000; Garrabou et al., 2009; Lejeusne et al., 2010). In this study, we report for the first time, in a Mediterranean coastal area, large year-to-year variations in the timing and duration of the cold-water period, i.e. the period during which subsurface water was continuously $\leqslant 13.5^{\circ} \mathrm{C}$.

Although the present study is mostly based on surface data, the data set on vertical distributions we acquired in 1999 shows that temperature largely drove the seasonal changes in $\sigma_{t}$ on the vertical. The water column remained vertically homogenous as long as subsurface water temperature was $\leqslant 13.0^{\circ} \mathrm{C}$, and showed an alternation of fully mixed and more stable conditions during the transition period when subsurface water temperature increased from $>13.0$ to $\leqslant 13.5^{\circ} \mathrm{C}$. During this period, a weak pycnocline developed in response to small increases in subsurface water temperature, and intermittent shoaling of the mixed layer was observed. Warming above $13.5^{\circ} \mathrm{C}$ led to a progressive increase in the vertical $\sigma_{t}$ gradient, with development of the summer thermocline. When available, vertical profiles recorded at the canyon head station showed that the main changes in the vertical structure of the water column occurred at the same temperature thresholds as observed at station PHYTOcLy in 1999.

In coastal waters of the Western Mediterranean, few studies have addressed the variability in the structure of the water column during the winter-spring transition. Moreover, the oldest data were acquired at low sampling frequency (i.e. fortnightly or monthly), which limits their usefulness in describing the winterspring transition. Nevertheless, the information reported for the 0-70 $\mathrm{m}$ upper layer in the coastal zones of the Balearic and Ligurian basins (Salat et al., 1978; Bustillos-Guzmán et al., 1995; Gómez and Gorski, 2003) is in good agreement with our observation that major changes in the water column structure occur upon crossing the subsurface water temperatures of 13.0 and $14.0^{\circ} \mathrm{C}$. Hence, keeping in mind that subsurface water temperature alone cannot provide full characterisation of the vertical structure of the water column, we use here subsurface temperature thresholds as proxies for that vertical structure in the Bay of Calvi, i.e. $\leqslant 13.0^{\circ} \mathrm{C}$ corresponds to vertical homogeneity of the water column, between $>13.0$ and $\leqslant 13.5^{\circ} \mathrm{C}$ is associated with alternation of vertically mixed and more stable conditions, and $\geqslant 13.5^{\circ} \mathrm{C}$ is the tipping point towards (slightly) stratified and more stable conditions.

\subsection{Specific aspects of the phytoplankton bloom in the Bay of Calvi}

Due to the high or very high sampling frequency used in the 15 years when there were Tchl $a$ time series at station PнyтосLY, all phytoplankton peaks were likely captured over the observed winter-spring periods, showing that the occurrence of bloom and non-bloom years was one of the main characteristics of the Bay of Calvi. This is different from reports in other Western Mediterranean areas where the winter-spring phytoplankton bloom developed every year in coastal waters, such as the Gulf of Naples (e.g. Ribera d'Alcalà et al., 2004; Orsini et al., 2004), the Gulf of Marseille (e.g. Travers, 1971; Grégori et al., 2001), the Bay 

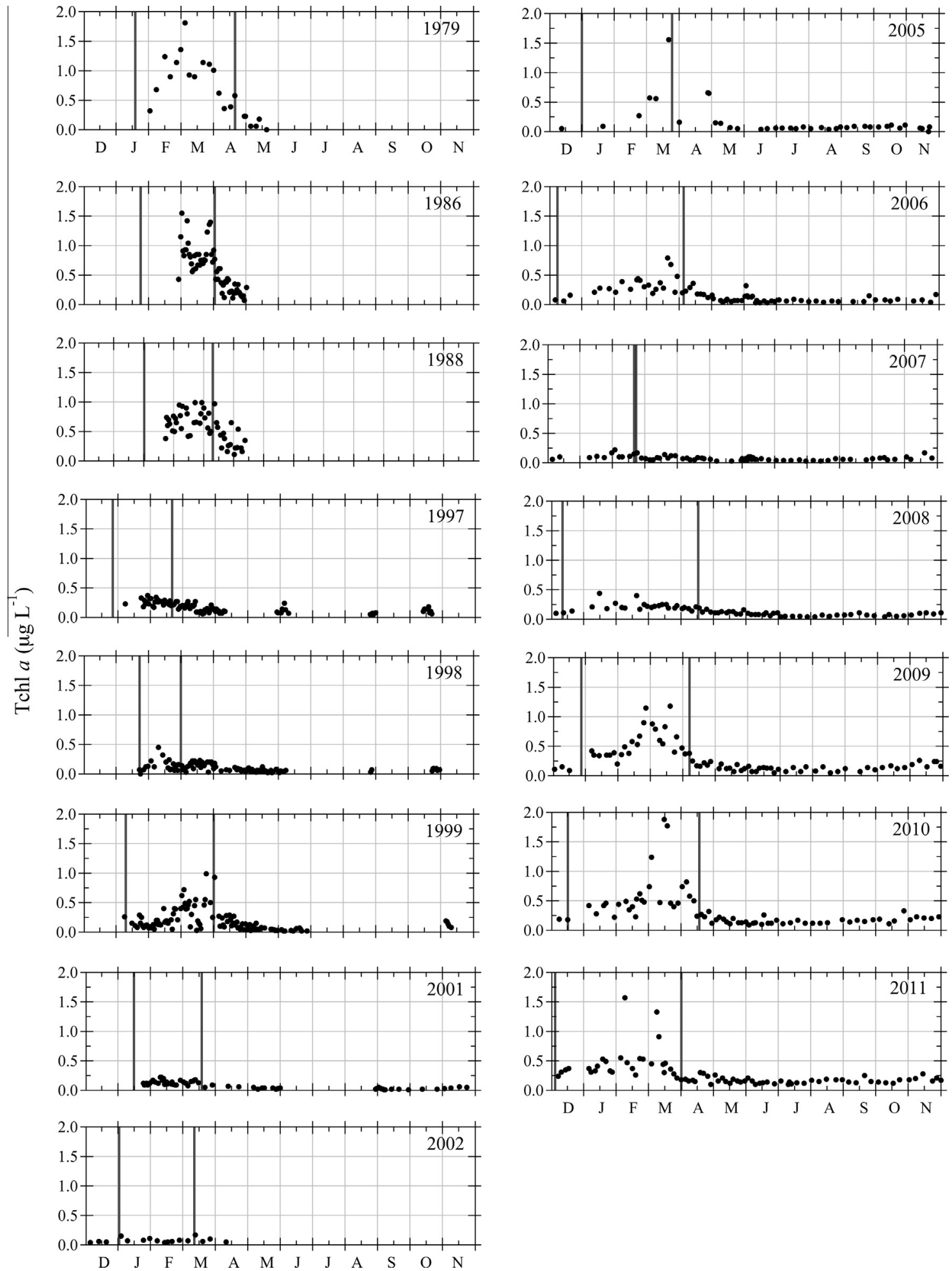

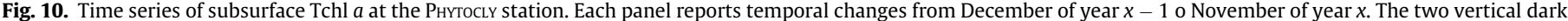
bars identify the limits of the cold-water periods $\left(\leqslant 13.5^{\circ} \mathrm{C}\right)$.

of Banuyls-sur-Mer (e.g. Neveux et al., 1975; Charles et al., 2005), and Blanes Bay (e.g. Herrera and Margalef, 1961; Mura et al., 1996).

Recent studies based on satellite-derived chl $a$ concentrations provided synoptic pictures of phytoplankton phenology in the Mediterranean Sea (e.g. D'Ortenzio and Ribera d'Alcalà, 2009; Olita et al., 2011; Lavigne et al., 2013). More specifically, D'Ortenzio and Ribera d'Alcalà (2009) and Lavigne et al. (2013) identified 7-9 bioregions, which they grouped into blooming, non blooming, and intermittently blooming areas. The latter were characterised by years with periods of intense biomass accumulation and other years without, and included the Northern Current. Although the Pнутосьу station is located very close to the coast, its phytoplankton phenology clearly belongs to the intermittent blooming regime. However, the intermittent-blooming character of the Bay of Calvi is not recognised on the maps of D'Ortenzio and Ribera d'Alcalà (2009) and Lavigne et al. (2013), who used spatial 
resolutions of 18 and $9 \mathrm{~km}$, respectively, and assigned the Calvi area and the northern half of the western Corsican coast to the blooming regime. This discrepancy between the maps in these publications and our observations is because the size of the Bay of Calvi corresponds to a single pixel size in the satellite images used in the above publications.

During bloom years at the Pнутосцу station, there were marked differences in the onset, date of maximum concentration, duration and intensity of the surface phytoplankton bloom. However despite these differences, all bloom years shared one key characteristic, i.e. Tchl $a$ always increased and peaked during the cold-water period, when subsurface water was $\leqslant 13.5^{\circ} \mathrm{C}$.

Based on our observations of the bloom development in 1999, we hypothesise that, in years when it when occurs, the phytoplankton bloom at station Pнутосцу starts and develops in winter in a homogenous water column with subsurface temperature $\leqslant 13.0^{\circ} \mathrm{C}$, continues in conditions of alternation between fully mixed and more stable water column with temperature between $>13.0$ and $\leqslant 13.5^{\circ} \mathrm{C}$, and collapses abruptly in the days that follow the end of the cold-water period, when stable conditions develop. We are aware that this pattern is based on only one series of detailed observations on the vertical distributions of temperature, $\sigma_{t}$ and Tchl $a$ and that it needs to be further confirmed by other field data. However, our hypothesis is grounded in both the robustness of the very detailed 1999 data series, and the fact that, in the available 15 Tchl $a$ time series at station Pнyтосьу, the phytoplankton bloom always occurred within the cold-water period. A few field studies have also reported the regular occurrence of winter blooms in vertically mixed coastal Mediterranean waters (Ribera d'Alcalà et al., 2004; Goffart and Hecq, 2005; Zingone et al., 2010). According to the latter study, those blooms are characterised by moderate chl $a$ concentrations vertically distributed down to the bottom, which result in winter depth-integrated biomass values that are comparable to those found in spring at the same station. Such blooms do not fit the usual idea that phytoplankton are blooming because of warming/stratification of the surface layer (e.g. Sverdrup, 1953; Estrada et al., 1985; Falkowski and Raven, 2007), and that stratifying or stratified conditions are a necessary preconditioning factor for the onset of the Mediterranean winter-spring bloom (e.g. Bustillos-Guzmán et al., 1995; Bonilla-Findji et al., 2010; Latasa et al., 2010). Our observations and those reported above indicate instead that phytoplankton blooms may be diverse in terms of patterns and formation mechanisms (e.g. Townsend et al., 1992; Behrenfeld, 2010; Chiswell, 2011). High phytoplankton biomass in the absence of thermal stratification could be explained by (1) the close-to-the-surface bottom, which keeps phytoplankton in layer that is always well illuminated (Zingone et al., 2010), (2) sustained periods of calm weather during which vertical mixing would be weak (Townsend et al., 1994), (3) rate of phytoplankton photoacclimation faster than vertical mixing (Morán and Estrada, 2005), and (4) decoupling between phytoplankton growth and grazing, which would make the loss term (grazing) smaller than the gain (growth) (Behrenfeld, 2010; Herrmann et al., 2013).

\subsection{Seasonal control of nutrient enrichment}

In the Bay of Calvi, previous field studies had suggested that surface nutrient replenishment was wind-dependent (Brohée et al., 1989; Goffart, 1992). In this study, results from the 1999 survey showed that wind events (mean daily wind speed $>5 \mathrm{~m} \mathrm{~s}^{-1}$ ) blowing during at least $48 \mathrm{~h}$ during the cold-water period, i.e. the period during which subsurface water was continuously $\leqslant 13.5^{\circ} \mathrm{C}$, were repeatedly followed by local increases in nutrients, which indicates that wind events induced vertical mixing that drove upward mixing of nutrient-rich deep waters. After the end of the cold-water period, i.e. as soon as seasonal stabilization of the water column started, wind events were not followed any more by injection of deep nutrients in the surface layer. This is because the $\sigma_{t}$ gradient prevented wind to cause strong vertical mixing, which stopped the upward flux of nutrients previously associated with vertical mixing, and as a consequence the surface layer became rapidly depleted in nutrients. It follows that wind intensity and water temperature interacted to deliver nutrients to the surface layer under specific hydrodynamical conditions, i.e. the presence of a vertically homogenous or temporarily and slightly stratified water column, which was characterised by subsurface water temperature $\leqslant 13.5^{\circ} \mathrm{C}$.

Bearing in mind that water depth in the western part of the Bay of Calvi ranges between 10 and $50 \mathrm{~m}$, i.e. shallower than the upper part of the deep nutrient reservoir, the rapid increases in nitrate observed after wind events were most likely due to onshore advection of nutrient-rich deeper water. This is consistent with the results of a 3D high-resolution model that investigated the effects of wind forcing on flow patterns and cross-shelf exchanges in the Calvi area during the homogenous winter and early spring conditions (Skliris et al., 2001b). Simulations performed with strong wind ( $10 \mathrm{~m} \mathrm{~s}^{-1}$ during $24 \mathrm{~h}$ ) showed that wind forcing was responsible for a drastic increase of cross-shore transport between the bay and the canyon area (3-4 times larger than in the no-wind case). We cannot fully exclude the occurrence of pulsed inputs of nutrient through resuspension of bottom sediments during wind events, but it is generally recognised that extensive meadows of Posidonia oceanica, such as those present in the Bay of Calvi, significantly buffer sediment resuspension (Gacia and Duarte, 2001; Duarte et al., 2013).

It thus appears that (1) the number of wind events during the cold-water period was the main driver of upward flux of nutrients associated with vertical mixing at the seasonal scale, (2) the presence of the canyon in front of the Bay of Calvi promoted exchanges between offshore nutrient-rich deep water and shallow coastal water, and (3) these exchanges were enhanced by wind forcing.

\subsection{Interannual control of nutrient enrichment}

Our time series shows that the Bay of Calvi oscillated between a subtropical pattern, characterised by low nutrient seasonality, and a temperate regime, with a well-marked increase in nutrient during the winter-spring period. As a consequence, the trophic status of the bay varied from very oligotrophic $\left(\mathrm{NO}_{3} \leqslant 1.0 \mu \mathrm{M}\right.$ throughout the year), when the subtropical pattern dominated, to mesotrophic $\left(\mathrm{NO}_{3}>1.0 \mu \mathrm{M}\right.$ during the cold-water period), in years characterised by the temperate regime. This stresses the important point that surface nutrient replenishment does not occur year after year in the Bay of Calvi, which is contrary to the well-established idea that, in the Western Mediterranean, vertical mixing systematically restores nutrients in the surface layer during winter thus leading to high nutrient concentrations during or at the end of winter in both coastal and offshore waters (e.g. Estrada et al., 1985; Bustillos-Guzmán et al., 1995; Marty et al., 2002).

We used the WII to investigate the link between the interannual variability of winter intensity, and that of nutrients during the cold-water periods. It follows from the relationships in Fig. 9 that, at the Pнyтосьy station at the interannual scale: (1) nutrient enrichment of surface waters, although variable interannually in intensity, was driven every year by wind forcing during the cold-water period; (2) wind-induced vertical mixing explained most of the interannual variability in surface nutrient stocks.

Despite the strong relationships between the WII and nutrient stocks, differences in nutrient availability were sometimes observed in years having the same WII. These differences were not correlated with changes in the predominant directions of wind 
events (Fig. 9). They were probably driven by processes affecting the upper layer of the western Corsican coastal waters at different, and often interconnected, temporal and spatial scales. For example, regional (but undocumented) variations in the dynamics of the mixed layer related to the complex topography and atmospheric inputs could presumably have been superimposed on the local drivers of vertical mixing and affect the nutrient contents of the surface layer.

Nutrient inputs from atmosphere are by nature highly episodic. They occur through rainwater and aeolian events, and are a potentially important source of macro- and micro-nutrients (N, P, Si, Fe, and other metals; Loÿe-Pilot et al., 1990; Guieu et al., 2014). In the Mediterranean Sea, the main natural source of land-derived particles is wind-blown Saharan dust. In Corsica, 75-95\% of the Saharan dust are deposited through rain, but the flux of dust particles is independent of the amount of rainfall (Loÿe-Pilot and Martin, 1996; Guerzoni and Molinaroli, 2005). Deposition of the remaining part of dust occurs by direct deposition of aerosols during periods without rain (Morales-Baquero et al., 2013). A 11-year survey (1984-1994) of Saharan dust inputs showed that the frequency and the magnitude of the events were minimum in winter (December-February) and maximum in spring (March-May) (Loÿe-Pilot and Martin, 1996). The atmospheric input of dissolved inorganic nitrogen (DIN, wet + dry deposition) measured over the 1984-1986 period in a pristine area of South Corsica (Bavella station) ranged from 46.0 to $54.8 \mathrm{mmol} \mathrm{m}^{-2} \mathrm{y}^{-1}$ (Loÿe-Pilot et al., 1990). More recently, the annual DIN flux (wet + dry deposition) measured between June 2001 and May 2002 at a controlled-access coastal station (Ostriconi) close to our Pнутосly station was 2 times smaller than that measured at Bavella, reaching only $25.4 \mathrm{mmol} \mathrm{m}^{-2} \mathrm{y}^{-1}$ (Markaki et al., 2010). According to Fig. 2 of Markaki et al. (2010), the atmospheric deposition of DIN was $\approx 4.5 \mathrm{mmol} \mathrm{m}^{-2}$ during the cold-water period of the mild (i.e. not very windy) winter of 2002 (January-March, 90 days), which represents a mean input of $0.05 \mathrm{mmol} \mathrm{m}^{-2} \mathrm{~d}^{-1}$. Assuming that the deposited DIN was diluted by mixing over the $40 \mathrm{~m}$ water column of the PHYTocLY station, then the atmospheric input of DIN accounted for only $3.8 \%$ of the inorganic nitrogenous stock during the cold-water period of winter $2002(0.33 \mu \mathrm{M}$, Table 3$)$. Although limited to one year, this observation suggests that wind-induced vertical mixing was the main factor explaining most of the interannual variability in the stock of surface nutrients in the Bay of Calvi during the cold-water periods, even during mild winters. It follows from the above considerations that, at the interannual scale, the main driver of vertical mixing events and resulting nutrient enrichments was the number of wind events during the cold-water period.

At the scale of the Western Mediterranean Sea, the depth reached by winter convection and its duration are key factors that determine the efficiency of the vertical mixing (Heimbürger et al., 2013), and the associated upward flux of nutrient. As in the Bay of Calvi, the intensity of winter convection in the Gulf of Lion and in the central Ligurian Sea (Medoc area and DyFAmEd site, respectively; Fig. 1A) shows strong interannual variability, i.e. warm years with very limited vertical mixing, and cold years where the water column can be mixed over its whole depth (Herrmann et al., 2009; Marty and Chiavérini, 2010). In the Gulf of Lion, extreme cascading events occurred in winter 1999 (Bethoux et al., 2002) and 2010 (Puig et al., 2013). Field observations and model simulation covering the 1999-2007 period described winter 2006 as stronger than the average, and showed that there was no convection during winter 2007 (Herrmann et al., 2009). At the DyFAmed site, in situ data acquired over the 1988-2008 period and model results indicated weak convection in winter 1998, intense but short convection in winter 1997, relatively shallow convection during winter 2002, strong and very strong convection events during winters 1988 and 2008, respectively, and long-lasting winter convection (e.g. more than 3 months) in 1999 (Heimbürger et al., 2013). The most remarkable mixing event over the 1995-2007 period was observed in February 2006, when convection occurred over the whole water column at the DyFAmED site (down to $>2000 \mathrm{~m}$; Marty and Chiavérini, 2010). Hence most of the interannual variability in the intensity of winter vertical mixing at the Dyfamed site and in the Medoc area was similar to that estimated by our WII in the Bay of Calvi, i.e. absence or very short winter convection in 2007 and 1998 , shallow mixing in 2002 , higher mixing in 1988 , long period of mixing in 1999, and intense mixing in 2006 and 2008. Consequently, it is likely that the years of cold/warm winters correspond to strong/weak convection, and to high/weak replenishment of nutrients in the surface layer in the whole Western Mediterranean.

\subsection{Interannual control of phytoplankton blooms}

We also used our WII to investigate the link between the interannual variability in winter intensity and mean surface Tchl $a$ during the cold-water periods. The fact that higher Tchl $a$ corresponded to higher WII in years characterised by mild and moderate winters indicates that the intensity of the bloom was then related to the frequency of wind events during the cold-water period, and that phytoplankton took advantage of nutrients brought by wind-induced vertical mixing to develop in the Bay of Calvi. For WII $\leqslant 3.5$, the trophic regime of the Bay of Calvi ranged from very oligotrophic to mesotrophic during mild and moderate winters, respectively, with correspondingly low to high Tchl $a$. Moreover, close examination of wind data shows that, during moderate winters $(1.3 \leqslant \mathrm{WII} \leqslant 3.5)$, year-to-year changes in the strength of the winter-spring phytoplankton bloom were related to small changes in the prevailing direction of wind events during the cold-water periods. In years with similar WII, higher Tchl $a$ values were observed in years with high frequency (59$88 \%$ ) of wind events blowing from the southwest and low frequency $(\leqslant 13 \%)$ of northeasterly wind (Fig. 9). In contrast, lower phytoplankton biomass was observed in years with higher frequency $(>13 \%)$ of northeasterly wind and lower (44-63\%) frequency of southwesterly winds. This can be interpreted as accumulation of phytoplankton biomass in the Bay of Calvi when the prevailing winds were almost always from the southwest, and high offshore transport in years when winds blew more frequently from the northeast thus eroding the developing phytoplankton bloom. This suggests that small changes in the prevailing direction of the wind events during the cold-water periods influenced the horizontal water circulation in the Bay of Calvi and thus the residence time of waters in the Bay, which affected the concentration of phytoplankton.

During severe winters (WII > 3.5) with increasing WII, nutrients increased up to their maximum concentrations and Tchl $a$ decreased progressively (Fig. 9). During the two most severe winters in the time series (2006 and 2008 , WII $\geqslant 4.3$ ), there was no phytoplankton bloom despite high nutrient availability. Such «high nutrient - low chlorophyll» conditions were relatively unexpected in a Mediterranean coastal area. They indicate that the development of phytoplankton biomass was limited by other factors than nutrient availability during winters 2006 and 2008. We discuss in turn three possible limiting factors: irradiance, grazing by zooplankton, and offshore export.

Irradiance is obviously key to photosynthesis, but it is generally high enough in Western Mediterranean waters to promote net phytoplankton growth even in homogeneous and vertically mixed water columns (Morán and Estrada, 2005; Zingone et al., 2010). In winters with high WII, the number of hours with bright sunshine between January and March was highest in winter 2008 (479 h, 
low Tchl $a$ ) and almost the same in winters 1979 (389 h, highest Tchl $a$ ), 2006 (361 h, low Tchl $a$ ) and 2010 (354 h, high Tchl $a$ ) (data from Météo France). Hence the «high nutrient - low chlorophyll» conditions observed during winters 2006 and 2008 cannot be explained by light limitation.

Zooplankton grazing is another factor that can exert a strong top-down control on phytoplankton biomass, and reduce drastically the standing stock. In Mediterranean coastal waters, the role of zooplankton grazing on phytoplankton biomass is under debate, as illustrated by the conclusions of two studies performed in the Bay of Villefranche-sur-Mer. García-Comas et al. (2011), analysing zooplankton collected with a Juday-Bogorov net (330 $\mu \mathrm{m}$ mesh size), reported a dominant bottom-up control of zooplankton biomass year long. On the other hand, Vandromme et al. (2011), who worked on zooplankton collected with a smaller mesh size (WP2 net, $200 \mu \mathrm{m}$ ), found that a top-down control of phytoplankton occurred every year from March to late October. We do not have enough information to discuss in any detail the role of zooplankton grazing at our sampling station. Nevertheless, the observation that, in the Bay of Calvi, mesozooplankton biomass collected weekly between January and April was 2-fold lower in 2006 and 2008 than in 2010 (Collignon, 2014) suggests that phytoplankton was not strongly controlled by grazers during the cold-water periods. This is in agreement with several studies reporting that grazing is low in the Western Mediterranean in winter in both coastal areas (Duarte et al., 1999; Agustí and Duarte, 2000; Zingone et al., 2010) and the open sea (Auger et al., 2014). Moreover, Behrenfeld (2010) showed that vertical mixing, which is essential for phytoplankton bloom formation, dilutes both predators and preys, whereas stratified conditions concentrate them. Hence we assume that zooplankton grazing controlled only moderately or not at all phytoplankton biomass during the cold-water periods in severe winters, and was not responsible for low Tchl $a$ during winters 2006 and 2008.

We assume instead that export to offshore nutrient-rich waters was likely the most important factor explaining the reduced phytoplankton biomass accumulation at very high WII, and that cross-shore transport was reinforced in 2006 and 2008, when high frequency of winds blowing from the northeast (18-25\%, Table 3) dominated. The former hypothesis is supported by modelling simulations showing that, in the Bay of Calvi, strong wind forcing $\left(10 \mathrm{~m} \mathrm{~s}^{-1}\right.$ during $24 \mathrm{~h}$ ) was responsible for a 3 -4-fold increase in cross-shore transport compared to no-wind situation (Skliris et al., 2001b). Accordingly, frequent and strong wind events blowing from the northeast could have generated instances of high cross-shore exchanges, which decreased the residence time of waters in the bay, and thus prevented the development and accumulation of phytoplankton biomass in the nutrient-rich coastal waters.

In summary, much of the interannual variability of phytoplankton bloom dynamics at the PHYTocly station can be interpreted as responses to interannual differences in wind-driven physical processes during the cold-water period, which both control the development of the phytoplankton bloom and drive cross-shore exchanges with offshore waters. Taking WII as a proxy for winter intensity shows that (1) there was no phytoplankton accumulation in mild winters; (2) moderate winters favored the buildup of phytoplankton biomass (bloom), whereas extremely severe winters characterised by a high frequency of northeasterly winds prevented it; and (3) vertical mixing controlled phytoplankton development through the agency of nutrient availability during moderate winters, in the absence of light limitation.

\subsection{Long-term changes in the Bay of Calvi and at larger Mediterranean scales}

No continuously increasing or decreasing trend with time was detected in WII from 1979 to 2011, but instead three successive periods were identified, characterised by moderate (1979-1988), mild (1989-1998) and highly variable winters (1999-2011), respectively. Extreme WII values were observed in two consecutive winters during the last decade (2007 and 2008, respectively), with corresponding minimum and very high values in both mean $\mathrm{NO}_{3}$ and $\mathrm{Si}(\mathrm{OH})_{4}$. Changes in winter intensity between the three periods were abrupt.

In a previous study based on 5 annual time series acquired at the Phytocly station (1979, 1986, 1988, 1997, and 1998), we had reported a continuous decrease of Tchl $a$ during the winter-spring period (Goffart et al., 2002). We had related this major change to increasing winter water temperature and decreasing wind intensity, and hypothesised that the changes in environmental conditions had been large enough to reduce vertical mixing and associated nutrient replenishment of the surface layer from 1979 to 1998. However, when considering the whole data set (19792011) and not only the five years included in our 2002 study, we found that there was no continuously increasing or decreasing trend in nutrient fertilisation of the surface layer and thus in the magnitude of the phytoplankton bloom. The apparent disagreement between our present results and those from our previous study are explained by the existence of the three successive periods in WII identified above. Indeed, the time series included in our first study consisted of years with continuously decreasing WII, leading to continuous decreases in both nutrient and Tchl $a$ during the winter-spring period between 1979 and 1998 (Fig. 7). However, WII became extremely variable from 1999 onwards, which was accompanied by high interannual variability in surface nutrient replenishment and phytoplankton bloom intensity. This highlights the relevance of time series to detect differences between fluctuations and trends.

The present study is focused on the links between environmental drivers and phytoplankton bloom dynamics in the Bay of Calvi, and does not address possible regime shifts that have been the focus of recent attention in the Mediterranean Sea (e.g. Conversi et al., 2010; MerMEx group, 2011; Cabrini et al., 2012). Nevertheless, three striking similarities between our observations and events elsewhere in the Northwestern Mediterranean Sea are: (1) the correspondence between the decadal changes in WII in the Bay of Calvi and the nearly similar decadal changes in environmental conditions reported in the Bay of Villefranche-sur-Mer (García-Comas et al., 2011), (2) the co-occurrence of decadal changes in WII in the Bay of Calvi and decadal variability in winter mixed layer depth reproduced by modelling at the Dyfamed site (Auger et al., 2014), and (3) the increasing occurrence of extreme events of strong winter mixing in both the Bay of Calvi and at the DyFAmED station in recent years (Marty and Chiavérini, 2010; Heimbürger et al., 2013). This indicates that the mechanisms we identified from the 1979 to 2011 period of observation in the Bay of Calvi are pertinent to other Northwestern Mediterranean areas, stressing the importance of winter conditions in determining the state of Mediterranean pelagic ecosystems. There is also evidence that decadal fluctuations similar to those of WII in the Bay of Calvi (1979-1988, 19891998, and 1999-2011) occurred in deposition of atmospheric dust, with the three successive periods characterised by deposition fluxes that were moderate-high (1984-1989; Loÿe-Pilot and Martin, 1996), low-moderate (1990-1998; Loÿe-Pilot and Martin, 1996; Guieu et al., 2010), and highly variable (19992011; Guieu et al., 2010; Ternon et al., 2010; Desboeufs, personal communication). The concomitance of decadal fluctuations in our WII and deposition fluxes of atmospheric dust suggests that the changes in WII we observed in the Bay of Calvi reflected atmospheric phenomena that were occurring at a much larger scale than the Northwestern Mediterranean basin. 


\section{Concluding remarks}

Using long-term observations (1979-2011) performed in the Bay of Calvi at the PнутосLy station, we characterise the effects of key environmental drivers on nutrient and phytoplankton dynamics in a Mediterranean coastal area free from local anthropogenic pressure. We showed that the nutrient and Tchl $a$ conditions of the sampled waters ranged from very oligotrophic (i.e. corresponding to a subtropical regime) to mesotrophic (i.e. matching a temperate regime) during physically mild and moderate winters, respectively, and high nutrient - low chlorophyll conditions during severe winters characterised by specific wind conditions (i.e. high frequency of northeasterly winds). This wide range of nutrient regimes over the years at a single station covers all phytoplankton growth conditions that have been reported to occur in the Western Mediterranean Sea. From high-frequency field data, we identified threshold values of physical variables below and above which they strongly influenced winter-spring nutrient availability and phytoplankton bloom characteristics. We described a mechanism that links winter physics, nutrient replenishment of the surface layer and phytoplankton dynamics under the different combinations of meteorological conditions that occurred during the 32 years of observations. This mechanism and the associated thresholds provide key information for ecologists and modellers who are interested in predicting biological production in the changing Mediterranean Sea.

\section{Acknowledgments}

The fieldwork was performed at STARESo (Oceanographic Field Station of the University of Liège, Belgium, close to the city of Calvi, Corsica). We thank Prof. Bernard Rentier, Pro-Rector of the University of Liège, who made this work possible. We thank Dr. Pierre Lejeune and all the StARESO S.A.S staff for their logistic support, with a special mention for Sylvain Plaza. We are grateful to Dr. Constantin Frangoulis for efficient assistance in the field in 1999 and to Marc Binard for providing temperature data. Data acquisition was supported by the University of Liège (Belgium), the Agence de l'Eau Rhône - Méditerranée - Corse (France), Ifremer (France) and STARESO S.A.S (France). We also thank three anonymous reviewers for their thorough and helpful comments on the manuscript.

\section{References}

Agustí, S., Duarte, C.M., 2000. Strong seasonality in phytoplankton cell lysis in the NW Mediterranean littoral. Limnology and Oceanography 45, 940-947.

Andersen, V., Prieur, L., 2000. One-month study in the open NW Mediterranean Sea (DYNAPROC experiment, May 1995): overview of the hydrobiogeochemical structures and effects of wind events. Deep-Sea Research I 47, 397-422.

Arin, L., Guillén, J., Segura-Noguera, M., Estrada, M., 2013. Open sea hydrographic forcing of nutrient and phytoplankton dynamics in a Mediterranean coastal ecosystem. Estuarine, Coastal and Shelf Science 133, 116-128.

Astraldi, M., Gasparini, G.P., Sparnocchia, S., 1994. The seasonal and interannual variability in the Ligurian-provencal basin. Coastal and Estuarine Studies 46 93-113.

Atlas, E.L., Hager, S.W., Gordon, L.I., Park, P.K., 1971. A Practical Manual for use of the Technicon Autoanalyzer in Seawater Nutrient Analyses; Revised. Technical Report 215. Department of Oceanography, Oregon State University.

Auger, P.A., Ulses, C., Estournel, C., Stemmann, L., Somot, S., Diaz, F., 2014. Interannual control of plankton communities by deep winter mixing and prey/predator interactions in the NW Mediterranean: Results from a 30-year 3D modeling study. Progress in Oceanography 124, 12-27.

Behrenfeld, M.J., 2010. Abandoning Sverdrup's critical depth hypothesis on phytoplankton blooms. Ecology 91, 977-989.

Bernardello, R., Cardoso, J.G., Bahamon, N., Donis, D., Marinov, I., Cruzado, A., 2012. Factors controlling interannual variability of vertical organic matter export and phytoplankton bloom dynamics - a numerical case-study for the NW Mediterranean Sea. Biogeosciences 9, 4233-4245.

Bernardi Aubry, F., Berton, A., Bastianini, M., Socal, G., Acri, F., 2004. Phytoplankton succession in a coastal area of the NW Adriatic, over a 10-year sampling period (1990-1999). Continental Shelf Research 24, 97-115.
Bethoux, J.-P., Prieur, L., 1983. Hydrologie et circulation en Méditerranée NordOccidentale. Pétrole et techniques 299, 25-34.

Bethoux, J.-P., Durrieu de Madron, X., Nyffeler, F., Tailliez, D., 2002. Deep water in the western Mediterranean: peculiar 1999 and 2000 characteristics, shelf formation hypothesis, variability since 1970 and geochemical inferences. Journal of Marine Systems 33-34, 117-131.

Boissery, P., Tomasino, C., Giraud, A., Valentini, C.-A., Andral, B., Bouchoucha, M., Sargian, P., Holon, F., Delaruelle, G., Descamp, P., Deter, J., Soriano, C., Durin, E., Barras, C., Jorissen, F., Thibaut, T., Meinesz, A., Thébault, H., Ody, D., Lejeune, P. Goffart, A., Pelaprat, C., Noël, C., Bernardin, L., 2013. Synthèse des réseaux de surveillance soutenus par l'Agence de l'Eau Rhône Méditerranée Corse - eaux côtières de Méditerranée - juin 2013. Agence de l'Eau Rhône Méditerranée Corse, 99pp.

Bonilla-Findji, O., Gattuso, J.P., Pizay, M.D., Weinbauer, M.G., 2010. Autotrophic and heterotrophic metabolism of microbial planktonic communities in an oligotrophic coastal marine ecosystem: seasonal dynamics and episodic events. Biogeosciences 7, 3491-3503.

Bosc, E., Bricaud, A., Antoine, D., 2004. Seasonal and interannual variability in algal biomass and primary production in the Mediterranean Sea, as derived from 4 years of SeaWiFS observations. Global Biogeochemical Cycles 18, GB1005.

Brohée, M., Goffart, A., Frankignoulle, M., Henri, V., Mouchet, A., Hecq, J.-H., 1989. Variations printanières des communautés planctoniques en Baie de Calvi (Corse) en relation avec les contraintes physiques locales. Cahiers de Biologie Marine 30, 321-330.

Bustillos-Guzmán, J., Claustre, H., Marty, J.-C., 1995. Specific phytoplankton signatures and their relationships to hydrographic conditions in the coastal northwestern Mediterranean Sea. Marine Ecology Progress Series 124, 247-258.

Cabrini, M., Fornasaro, D., Cossarini, G., Lipizer, M., Virgilio, D., 2012. Phytoplankton temporal changes in a coastal northern Adriatic site during the last 25 years. Estuarine, Coastal and Shelf Science 115, 113-124.

Cerrano, C., Bavestrello, G., Bianchi, N., Cattaneo-Vietti, R., Bava, S., Morganti, C., Morri, C., Picco, P., Sara, G., Schiaparelli, S., Antonio, S., Sponga, F., 2000. A catastrophic mass-mortality episode of gorgonians and other organisms in the Ligurian Sea (North-western Mediterranean), summer 1999. Ecology Letters 3, 284-293.

Charles, F., Lantoine, F., Brugel, S., Chrétiennot-Dinet, M.-J., Quiroga, I., Rivière, B., 2005. Seasonal survey of the phytoplankton biomass, composition and production in a littoral NW Mediterranean site, with special emphasis on the picoplanktonic contribution. Estuarine, Coastal and Shelf Science 65, 199-212.

Chiswell, S.M., 2011. Annual cycles and spring blooms in phytoplankton: don't abandon Sverdrup completely. Marine Ecology Progress Series 443, 39-50.

Cloern, J.E., 1996. Phytoplankton bloom dynamics in coastal ecosystems: a review with some general lessons from sustained investigation of San Francisco Bay, California. Reviews of Geophysics 34, 127-168.

Collignon, A., 2014. Abondance et variabilité des méduses en Baie de Calvi (Corse). PhDThesis, University of Liège, Belgium, 204pp.

Conversi, A., Fonda Umani, S., Peluso, T., Molinero, J.C., Santojanni, A., Edwards, M., 2010. The Mediterranean Sea regime shift at the end of the 1980s, and intriguing parallelisms with other European basins. PLoS ONE 5, e10633.

Crise, A., Allen, J.I., Baretta, J., Crispi, G., Mosetti, R., Solidoro, C., 1999. The Mediterranean pelagic ecosystem response to physical forcing. Progress in Oceanography 44, 219-243.

Djenidi, S., 1985. Observations au large de Calvi en régime d'été. Bulletin de la Société Royale des Sciences de Liège, 54.

Djenidi, S., Nihoul, J.C.J., Clément, F., Salas de Leon, D., 1987. The Modem contribution to Medalpex. Annales Geophysicae, 3-12.

D’Ortenzio, F., Prieur, L., 2012. The upper mixed layer. In: Stambler, N. (Ed.), Life in the Mediterranean Sea: A look at habitat changes. Nova Science Publisher, pp. $127-156$.

D'Ortenzio, F., Ribera d'Alcalà, M., 2009. On the trophic regimes of the Mediterranean Sea: a satellite analysis. Biogeosciences 6, 139-148.

Duarte, C.M., Agustí, S., 2004. Controls on planktonic metabolism in the Bay of Blanes, northwestern Mediterranean littoral. Limnology and Oceanography 49, 2162-2170.

Duarte, C.M., Agustí, S., Kennedy, H., Vaqué, D., 1999. The Mediterranean climate as a template for Mediterranean marine ecosystems: the example of the northeast Spanish littoral. Progress in Oceanography 44, 245-270.

Duarte, C.M., Losada, I.J., Hendriks, I.E., Mazarrasa, I., Marbà, N., 2013. The role of coastal plant communities for climate change mitigation and adaptation. Nature Climate Change 3, 961-968.

Estrada, M., 1996. Primary production in the northwestern Mediterranean. Scientia Marina 60, 55-64.

Estrada, M., Vives, F., Alcaraz, M., 1985. Life and the productivity of the open ocean. In: Margalef, R. (Ed.), Western Mediterranean. Pergamon Press, pp. 148-197.

Estrada, M., Marrasé, C., Latasa, M., Berdalet, E., Delgado, M., Riera, T., 1993. Variability of deep chlorophyll maximum characteristics in the Northwestern Mediterranean. Marine Ecology Progress Series 92, 289-300.

Evans, G.T., Parslow, J.S., 1985. A model of annual plankton cycles. Biological Oceanography 3, 327-347.

Falkowski, P.G., Raven, J.A., 2007. Photosynthesis and Primary Production in Nature. In: Aquatic photosynthesis, second ed., Princeton University Press, pp. 319-363.

Francour, P., Boudouresque, C.-F., Harmelin, J.-G., Harmelin-Vivien, M.-L., Quignard, J.-P., 1994. Are the Mediterranean waters becoming warmer? Information from biological indicators. Marine Pollution Bulletin 28, 523-526. 
Gacia, E., Duarte, C.M., 2001. Sediment retention by a Mediterranean Posidonia oceanica meadow: the balance between deposition and resuspension. Estuarine, Coastal and Shelf Science 52, 505-514.

García-Comas, C., Stemmann, L., Ibanez, F., Berline, L., Mazzocchi, M.G., Gasparini, S., Picheral, M. Gorsky, G., 2011. Zooplankton long-term changes in the NW Mediterranean Sea: Decadal periodicity forced by winter hydrographic conditions related to large-scale atmospheric changes? Journal of Marine Systems 87, 216-226.

Garrabou, J., Coma, R., Bensoussan, N., Bally, M., Chevaldonné, P., Cigliano, M., Diaz, D., Harmelin, J.G., Gambi, M.C., Kersting, D.K., Ledoux, J.B., Lejeusne, C., Linares, C., Marschal, C., Pérez, T., Ribes, M., Romano, J.C., Serrano, E., Teixido, N., Torrents, O., Zabala, M., Zuberer, F., Cerrano, C., 2009. Mass mortality in Northwestern Mediterranean rocky benthic communities: effects of the 2003 heat wave. Global Change Biology 15, 1090-1103.

Gobert, S., Kyramarios, M., Lepoint, G., Pergent-Martini, C., Bouquegneau, J.-M., 2003. Variations à différentes échelles spatiales de l'herbier à Posidonia oceanica (L.) Delile; effets sur les paramètres physico-chimiques du sédiment. Oceanologica Acta 26, 199-207.

Goffart, A., 1992. Influence des contraintes hydrodynamiques sur la structure des communautés phytoplanctoniques du bassin Liguro-Provençal (secteur Corse). $\mathrm{PhD}$ Thesis, University of Liège, Belgium, 163pp.

Goffart, A., Hecq, J.-H., 2005. Composition et écologie du phytoplancton en Méditerranée: évolution à court et à long terme des communautés phytoplanctoniques du bassin liguro-provençal (secteur corse). Work awarded by the prize of the "Académie Royale des Sciences, des Lettres \& des Beaux-Arts de Belgique, groupe de Biologie Végétale», 71pp.

Goffart, A., Hecq, J.-H., Prieur, L., 1995. Contrôle du phytoplancton du bassin ligure par le front liguro-provençal (secteur corse). Oceanologica Acta 18, 329-342.

Goffart, A., Hecq, J.-H., Legendre, L., 2002. Changes in the development of the winter-spring phytoplankton bloom in the Bay of Calvi (NW Mediterranean) over the last two decades: a response to changing climate? Marine Ecology Progress Series 236, 45-60.

Gómez, F., Gorski, G., 2003. Annual microplankton cycles in Villefranche Bay, Ligurian Sea, NW Mediterranean. Journal of Plankton Research 25, 323-339.

Gordon, L.I., Jennings, J.C., Ross Jr., A.A., Krest, J.M., 1993. A suggested protocol for continuous flow automated analysis of seawater nutrients (phosphate, nitrate, nitrite and silicic acid) in the WOCE Hydrographic Program and the Joint Global Ocean Fluxes Study. WOCE Hydrographic Program Office, Methods Manual WHPO, 91-1.

Grégori, G., Colosimo, A., Denis, M., 2001. Phytoplankton group dynamics in the Bay of Marseille during a 2-year survey based on analytical flow cytometry. Cytometry 44, 247-256.

Guerzoni, S., Molinaroli, E., 2005. Input of various chemicals transported by Saharan dust and depositing at the sea surface in the Mediterranean Sea. In: Saliot, A (Ed.), The Mediterranean Sea. The Handbook of Environmental Chemistry, v. 5, Part K, Springer Science, pp. 237-268.

Guieu, C., Loÿe-Pilot, M.D., Benyahya, L., Dufour, A., 2010. Spatial variability of atmospheric fluxes of metals ( $\mathrm{Al}, \mathrm{Fe}, \mathrm{Cd}, \mathrm{Zn}$ and $\mathrm{Pb}$ ) and phosphorus over the whole Mediterranean from a one-year monitoring experiment: biogeochemical implications. Marine Chemistry 120, 164-178.

Guieu, C., Aumont, O., Paytan, A., Bopp, L., Law, C.S., Mahowald, N., Achterberg, E.P., Marañón, E., Salihoglu, B., Crise, A., Wagener, T., Herut, B., Desboeufs, K., Kanakidou, M., Olgun, N., Peters, F., Pulido-Villena, E., Tovar-Sanchez, A., Völker, C. 2014. The significance of the episodic nature of atmospheric deposition to Low Nutrient Low Chlorophyll regions. Global Biogeochemical Cycles 28, 11791198.

Heimbürger, L.-E., Lavigne, H., Migon, C., D’Ortenzio, F., Estournel, C., Coppola, L., Miquel, J.-C., 2013. Temporal variability of vertical export flux at the DYFAMED time-series station (Northwestern Mediterranean Sea). Progress in Oceanography 119, 59-67.

Herrera, J., Margalef, R., 1961. Hidrografía y fitoplancton de las costas de Castellón, de julio de 1958 a junio de 1959. Investigación Pesquera 20, 17-63.

Herrmann, M., Bouffard, J., Béranger, K., 2009. Monitoring open-ocean deep convection from space. Geophysical Research Letters 36, L03606.

Herrmann, M., Diaz, F., Estournel, C., Marsaleix, P., Ulses, C., 2013. Impact of atmospheric and oceanic interannual variability on the Northwestern Mediterranean Sea pelagic planktonic ecosystem and associated carbon cycle. Journal of Geophysical Research: Oceans 118, 5792-5813.

Hoffmann, L., Renard, R., Demoulin, V., 1992. Phenology, growth and biomass of Cystoseira balearica in Calvi (Corsica). Marine Ecology Progress Series 80, 249254.

Latasa, M., Scharek, R., Vidal, M., Vila-Reixach, G., Gutiérrez-Rodríguez, A., Emelianov, M., Gasol, J.M., 2010. Preferences of phytoplankton groups for waters of different trophic status in the northwestern Mediterranean Sea. Marine Ecology Progress Series 407, 27-42.

Lavigne, H., D’Ortenzio, F., Migon, C., Claustre, H., Testor, P., Ribera d'Alcalà, M., Lavezza, R., Houpert, L., Prieur, L., 2013. Enhancing the comprehension of mixed layer depth control on the Mediterranean phytoplankton phenology. Journal of Geophysical Research: Oceans 118, 3416-3430.

Lazzari, P., Solidoro, C., Ibello, V., Salon, S., Teruzzi, A., Béranger, K., Colella, S., Crise, A., 2012. Seasonal and inter-annual variability of plankton chlorophyll and primary production in the Mediterranean Sea: a modelling approach. Biogeosciences 9, 217-233.

Legendre, L., 1990. The significance of microalgal blooms for fisheries and for the export of particulate organic carbon in oceans. Journal of Plankton Research 12, 681-699.
Lejeusne, C., Chevaldonné, P., Pergent-Martini, C., Boudouresque, C.F., Perez, T. 2010. Climate change effects on a miniature ocean: the highly diverse, highly impacted Mediterranean Sea. Trends in Ecology and Evolution 25, 250-260.

Levy, M., Mémery, L., André, J.M., 1998. Simulation of primary production and export fluxes in the northwestern Mediterranean Sea. Journal of Marine Research 56, 197-238.

Licandro, P., Ibañez, F., Etienne, M., 2006. Long-term fluctuations (1974-1999) of the salps Thalia democratica and Salpa fusiformis in the northwestern Mediterranean Sea: relationships with hydroclimatic variability. Limnology and Oceanography 51, 1832-1848.

Lorenzen, C.J., 1967. Determination of chlorophyll and phaeopigments spectrophotometric equations. Limnology and Oceanography 12, 343-347.

Loÿe-Pilot, M.-D., Martin, J.-M., 1996. Saharan dust input to the western Mediterranean: an eleven years record in Corsica. In: Guerzoni, S., Chester, S. (Eds.), The Impact of Desert Dust Across the Mediterranean. Kluwer Academic Publishers, Norwell, pp. 191-199.

Loÿe-Pilot, M.-D., Martin, J.-M., Morelli, J., 1990. Atmospheric input of inorganic nitrogen to the western Mediterranean. Biogeochemistry 9, 117-134.

Mann, K.H., Lazier, J.R.N., 1996. Dynamics of Marine Ecosystems: Biological Physical Interactions in the Oceans. Blackwell Publishing, New York, 496pp.

Mantoura, R.F.C., Llewellyn, C.A., 1983. The rapid determination of algal chlorophyl and carotenoid pigments and their breakdown products in natural waters by reverse-phase high performance liquid chromatography. Analytica Chimica Acta 151, 297-314.

Markaki, Z., Loÿe-Pilot, M.D., Violaki, K., Benyahya, L., Mihalopoulos, N., 2010 Variability of atmospheric deposition of dissolved nitrogen and phosphorus in the Mediterranean and possible link to the anomalous seawater N/P ratio. Marine Chemistry 120, 187-194.

Marty, J.-C., Chiavérini, J., 2010. Hydrological changes in the Ligurian Sea (NW Mediterranean, DYFAMED site) during 1995-2007 and biogeochemical consequences. Biogeosciences 7, 2117-2128.

Marty, J.-C., Chiavérini, J., Pizay, M.-D., Avril, B., 2002. Seasonal and interannual dynamics of nutrients and phytoplankton pigments in the western Mediterranean Sea at the DYFAMED time-series station (1991-1999). DeepSea Research 49, 1965-1985.

MerMex Group: Durrieu de Madron, X., Guieu, C., Sempéré, R., Conan, P., Cossa, D. D’Ortenzio, F., Estournel, C., Gazeau, F., Rabouille, C., Stemmann, L., Bonnet, S., Diaz, F., Koubbi, P., Radakovitch, O., Babin, M., Baklouti, M., Bancon-Montigny, C., Belviso, S., Bensoussan, N., Bonsang, B., Bouloubassi, I., Brunet, C., Cadiou, J.F., Carlotti, F., Chami, M., Charmasson, S., Charrière, B., Dachs, J., Doxaran, D., Dutay, J.C., Elbaz-Poulichet, F., Eléaume, M., Eyrolles, F., Fernandez, C., Fowler, S. Francour, P., Gaertner, J.C., Galzin, R., Gasparini, S., Ghiglione, J.F., Gonzalez, J.L., Goyet, C., Guidi, L., Guizien, K., Heimbürger, L.E., Jacquet, S.H.M., Jeffrey, W.H., Joux, F., Le Hir, P., Leblanc, K., Lefèvre, D., Lejeusne, C., Lemé, R., Loÿe-Pilot, M.D., Mallet, M., Méjanelle, L., Mélin, F., Mellon, C., Mérigot, B., Merle, P.L., Migon, C., Miller, W.L., Mortier, L., Mostajir, B., Mousseau, L., Moutin, T., Para, J., Pérez, T., Petrenko, A., Poggiale, J.C., Prieur, L., Pujo-Pay, M., Pulido, V., Raimbault, P., Rees, A.P., Ridame, C., Rontani, J.F., Ruiz Pino, D., Sicre, M.A., Taillandier, V., Tamburini, C., Tanaka, T., Taupier-Letage, I., Tedetti, M., Testor, P., Thébault, H., Thouvenin, B., Touratier, F., Tronczynski, J., Ulses, C., Van Wambeke, F., Vantrepotte, V., Vaz, S., Verney, R., 2011. Marine ecosystems' responses to climatic and anthropogenic forcings in the Mediterranean. Progress in Oceanography 91, pp. 97-166.

Millot, C., 1991. Mesoscale and seasonal variabilities of the circulation in the Western Mediterranean. Dynamics of Atmospheres and Oceans 15, 179-214.

Millot, C., 1999. Circulation in the western Mediterranean Sea. Journal of Marine Systems 20, 423-442.

Morales-Baquero, R., Pulido-Villena, E., Reche, I., 2013. Chemical signature of Saharan dust on dry and wet atmospheric deposition in the south-western Mediterranean region. Tellus B 65, 18720.

Morán, X.A.G., Estrada, M., 2005. Winter pelagic photosynthesis in the NW Mediterranean. Deep Sea Research Part I: Oceanographic Research Papers 52, $1806-1822$.

Morel, A., André, J.M., 1991. Pigment distribution and primary production in the western Mediterranean as derived and modeled from coastal zone color scanner observations. Journal of Geophysical Research 96, 12685-12698.

Mozetič, P., Solidoro, C., Cossarini, G., Socal, G., Precali, R., Francé, J., Bianchi, F., Vittor, C., Smodlaka, N., Fonda Umani, S., 2010. Recent trends towards oligotrophication of the northern adriatic: evidence from chlorophyll a time series. Estuaries and Coasts 33, 362-375.

Mura, M.P., Agustí, S., Cebrián, J., Satta, M.P., 1996. Seasonal Variability of Phytoplankton Biomass and Community Composition in Blanes Bay (19921994). Publicaciones Especiales. Instituto Espanol de Oceanografia 22, pp. 2329.

Neveux, J., Fiala, M., Jacques, G., Panouse, M., 1975. Phytoplancton et matériel particulaire à Banyuls-sur-Mer (Golf du Lion). Vie et Milieu 25, 85-98.

Ninčević Gladan, Ž., Marasović, I., Grbec, B., Skejić, S., Bužančić, M., Kušpilić, G., Matijević, S., Matić, F., 2010. Inter-decadal Variability in Phytoplankton Community in the Middle Adriatic (Kaštela Bay) in Relation to the North Atlantic Oscillation. Estuaries and Coasts 33, 376-383.

Nykjaer, L., 2009. Mediterranean Sea surface warming 1985-2006. Climate Research 39, 11-17.

Olita, A., Sorgente, R., Ribotti, A., Fazioli, L., Perilli, A., 2011. Pelagic primary production in the Algero-Provençal Basin by means of multisensor satellite data: focus on interannual variability and its drivers. Ocean Dynamics 61, 10051016. 
Orsini, L., Procaccini, G., Sarno, D., Montresor, M., 2004. Multiple rDNA ITS-types within the diatom Pseudo-nitzschia delicatissima (Bacillariophyceae) and their relative abundances across a spring bloom in the Gulf of Naples. Marine Ecology Progress Series 271, 87-98.

Paerl, H.W., 1988. Nuisance phytoplankton blooms in coastal, estuarine, and inland waters. Limnology and Oceanography 33, 823-847.

Pinca, S., Dallot, S., 1995. Meso- and macrozooplankton composition patterns related to hydrodynamic structures in the Ligurian Sea (Trophos-2 experiment, April-June 1986). Marine Ecology Progress Series 126, 49-65.

Puig, P., Durrieu de Madron, X., Salat, J., Schroeder, K., Martín, J., Karageorgis, A.P., Palanques, A., Roullier, F., Lopez-Jurado, J.L., Emelianov, M., Moutin, T., Houpert, L., 2013. Thick bottom nepheloid layers in the western Mediterranean generated by deep dense shelf water cascading. Progress in Oceanography $111,1-23$.

Ribera d'Alcalà, M., Conversano, F., Corato, F., Licandro, P., Mangoni, O., Marino, D., Mazzocchi, M.G., Modigh, M., Montresor, M., Nardella, N., Saggiomo, V., Sarno, D., Zingone, A., 2004. Seasonal patterns in plankton communities in a pluriannual time series at a coastal Mediterranean site (Gulf of Naples): an attempt to discern recurrences and trends. Scientia Marina 68, 65-83.

Salat, J., Font, J., Cruzado, A., 1978. Datos oceanogréficos frente a Barcelone (19751976). Datos Informativos. Instituto de Investigaciones Pesqueras (CSIC) 5, 1 73.

Salat, J., Puig, P., Latasa, M., 2010. Violent storms within the Sea: dense water formation episodes in the NW Mediterranean. Advances in Geosciences 26, $53-$ 59.

Santoleri, R, Böhm, E, Schiano, M.E, 1994. The sea surface temperature of the Western Mediterranean Sea: historical satellite thermal data. In: La Violette, P.E. (Ed.), Seasonal and interannual variability of the Western Mediterranean Sea. Coastal and Estuarine Studies, American Geophysical Union, 46, pp. 155176.

Sara, G., Lo Martire, M., Sanfilippo, M., Pulicano, G., Cortese, G., Mazzola, A., Manganaro, A., Pusceddu, A., 2011. Impacts of marine aquaculture at large spatial scales: evidences from $\mathrm{N}$ and $\mathrm{P}$ catchment loading and phytoplankton biomass. Marine Environmental Research 71, 317-324.

SCOR-UNESCO, 1966. Determination of photosynthetic pigments in sea water. Monographs on oceanographic methodology 1, 11-18.

Siokou-Frangou, I., Christaki, U., Mazzocchi, M.G., Montresor, M., Ribera d'Alcalà, M., Vaqué, D., Zingone, A., 2010. Plankton in the open Mediterranean Sea: a review. Biogeosciences 7, 1543-1586.

Skliris, N., Elkalay, K., Goffart, A., Frangoulis, C., Hecq, J.-H., 2001a. One-dimensional modelling of the plankton ecosystem of the northwestern Corsican coastal area in relation to meteorological constraints. Journal of Marine Systems 27, 337 362.

Skliris, N., Goffart, A., Hecq, J.-H., Djenidi, S., 2001b. Shelf-slope exchanges associated with a steep submarine canyon off Calvi (Corsica, NW Mediterranean Sea): a modeling approach. Journal of Geophysical Research 106, 19883-19901.

Skliris, N., Sofianos, S., Gkanasos, A., Mantziafou, A., Vervatis, V., Axaopoulos, P., Lascaratos, A., 2011. Decadal scale variability of sea surface temperature in the
Mediterranean Sea in relation to atmospheric variability. Ocean Dynamics 62, $13-30$.

Sournia, A., Brylinski, J.M., Dallot, S., LeCorre, P., Leveau, M., Prieur, L., Froget, C., 1990. Fronts hydrologiques au large des côtes françaises: les sites-ateliers du programme Frontal. Oceanologica Acta 13, 413-437.

Sverdrup, H.U., 1953. On conditions for the vernal blooming of phytoplankton. Journal du Conseil International pour l'Exploration de la Mer 18, 287-295.

Ternon, E., Guieu, C., Loÿe-Pilot, M.-D., Leblond, N., Bosc, E., Gasser, B., Martin, J., Miquel, J.-C., 2010. The impact of Saharan dust on the particulate export in the water column of the North Western Mediterranean Sea. Biogeosciences 7, 809826.

Townsend, D.W., Keller, M.D., Sieracki, M.E., Ackleson, S.G., 1992. Spring phytoplankton blooms in the absence of vertical water column stratification. Nature 360, 59-62.

Townsend, D.W., Cammen, L.M., Holligan, P.M., Campbell, D.E., Pettigrew, N.R., 1994. Causes and consequences of variability in the timing of spring phytoplankton blooms. Deep-Sea Research I 41, 747-765.

Travers, M., 1971. Diversité du microplancton du Golfe de Marseille. Marine Biology 8, 308-343.

Tréguer, P., Le Corre, P., 1975. Manuel d'analyse des sels nutritifs dans l'eau de mer. Laboratoire d'Océanographie Chimique, Université de Bretagne Occidentale, Brest, 110pp.

Vandromme, P., Stemmann, L., Berline, L., Gasparini, S., Mousseau, L., Prejger, F., Passafiume, O., Guarini, J.M., Gorsky, G., 2011. Inter-annual fluctuations of zooplankton communities in the Bay of Villefranche-sur-mer from 1995 to 2005 (Northern Ligurian Sea, France). Biogeosciences 8, 3143-3158.

Vidussi, F., Marty, J.-C., Chiavérini, J., 2000. Phytoplankton pigment variations during the transition from spring bloom to oligotrophy in the northwestern Mediterranean sea. Deep Sea Research Part I: Oceanographic Research Papers 47, 423-445.

Williams, R., Claustre, H., 1991. Photosynthetic pigments as biomarkers of phytoplankton populations and processes involved in the transformation of particulate organic matter at the Biotrans site $\left(47^{\circ} \mathrm{N}, 20^{\circ} \mathrm{W}\right)$. Deep-Sea Research 38, 347-355.

Williams, R.G., Follows, M.J., 2003. Physical transport of nutrients and the maintenance of biological production. In: Fasham, M. (Ed.), Ocean Biogeochemistry: the Role of the Ocean Carbon Cycle in Global Change. Springer, pp. 19-51.

Zapata, M., Rodríguez, F., Garrido, J.L., 2000. Separation of chlorophylls and carotenoids from marine phytoplankton: a new HPLC method using a reversed phase C8 column and pyridine containing mobile phases. Marine Ecology Progress Series 195, 29-45.

Zingone, A., Casotti, R., Ribera d'Alcalà, M., Scardi, M., Marino, D., 1995. «St Martin's Summern: the case of an autumn phytoplankton bloom in the Gulf of Naples (Mediterranean Sea). Journal of Plankton Research 17, 575-593.

Zingone, A., Dubroca, L., Iudicone, D., Margiotta, F., Corato, F., Ribera d’Alcalà, M., Saggiomo, V., Sarno, D., 2010. Coastal phytoplankton do not rest in winter. Estuaries and Coasts 33, 342-361. 